\title{
White defects on enamel: Diagnosis and anatomopathology: Two essential factors for proper treatment (part 1)
}

\section{Taches blanches de l'émail : diagnostic et anatomopathologie : deux données indispensables pour bien les traiter (partie 1)}

\author{
Maud DENIS ${ }^{\mathrm{a},{ }^{*}, \mathrm{~b}}$, Anthony ATLAN ${ }^{\mathrm{a}, \mathrm{c}}$, Elsa VENNAT ${ }^{\mathrm{d}}$, Gil TIRLET ${ }^{\mathrm{a}, \mathrm{e}}$, \\ Jean-Pierre ATTAL ${ }^{\mathrm{a}, \mathrm{b}}$ \\ ${ }^{a}$ Hôpital Charles-Foix, 12, rue de la République, 94200 Ivry-sur-Seine, France \\ ${ }^{\mathrm{b}}$ Unité de recherche biomatériaux innovations et interfaces, hôpital Charles-Foix, université \\ Paris Descartes, 12, rue de la République, 94200 Ivry-sur-Seine, France \\ ${ }^{\mathrm{c}} 98$ bis, rue Bobillot, 75013 Paris, France \\ ${ }^{\mathrm{d}}$ École central Paris, laboratoire MSSMat, Grande Voie des Vignes, 92295 Chatenay-Malabry \\ cedex, France \\ e234, boulevard Raspail, 75014 Paris, France
}

Available online: XXX / Disponible en ligne : XXX

\section{Summary}

Early-stage caries (white spots), fluoroses, traumatic hypomineralizations and molar incisive hypomineralization (MIH) all present, to differing degrees, clinical symptoms involving white marks on the enamel. This article shows that proper diagnosis leads to better understanding of the three-dimensional aspects of the lesion, thereby ensuring the appropriate choice of a specific treatment.

(C) 2013 CEO. Published by Elsevier Masson SAS. All rights reserved

\section{Key-words}

- Enamel hypomineralization.

- White spot.

- Fluorosis.

- Traumatic hypomineralization.

\section{Résumé}

Les caries initiales (white spots), les fluoroses, les hypominéralisations traumatiques et les hypominéralisations molaires incisives $(\mathrm{MIH})$ présentent toutes, à différents stades, un tableau clinique comportant des lésions blanches de l'émail. Nous montrerons dans cet article que l'établissement du bon diagnostic assure une meilleure appréhension tridimensionnelle de la lésion garantissant d'adopter l'adéquat traitement spécifique.

(C) 2013 CEO. Édité par Elsevier Masson SAS. Tous droits réservés

\section{Mots-clés}

- Hypominéralisation amélaire.

- White spot.

- Fluorose.

- Hypominéralisation traumatique.
* Correspondence and reprints / Correspondance et tirés à part :

Maud DENIS', Unité de recherche biomatériaux innovations et interfaces, université Paris Descartes, 1, rue Maurice-Arnoux, 92120 Montrouge, France. e-mail address / Adresse e-mail : dr.denis.maud@gmail.com 
- MIH.

- Erosion-infiltration.

In everyday practice, the dental surgeon, under increasing pressure from patients with esthetic concerns, is more and more often called on to treat abnormalities in tooth color. The lack of good initial training in this field unfortunately means that the etiological diagnosis of such problems is often perceived by the physician as an awkward hurdle to overcome. This is no doubt why dentists often prefer to abstain from proposing treatment, or sometimes even evacuate the problem-and the lesion-with the bur. And yet there exists today a basic range of appropriate treatments comprising whitening, erosion/infiltration and/or micro-/mega-abrasion. However, before opting for one or other of these treatments, it is essential to understand the etiology of the lesion. This article will first look at the optical mechanism which explains the white appearance of areas of hypomineralization in the enamel and then examine one by one the various etiologies, describing precisely the corresponding lesions and their consequences in terms of type of treatment and its limitations. A second article will be devoted more specifically to the treatment of these spots by erosion-infiltration.

\section{The feature common to all white defects: hypomineralization}

The presence of a visible white area on the tooth surface is due solely to a defect in the enamel. In this clinical situation, the dentin is never involved. Healthy enamel is the most highly mineralized tissue in the organism, $96 \%$ of its composition (by weight) being represented by hydroxyapatite; the remaining $4 \%$ are organic fluids. Conversely, in the presence of a white spot (WS), this mineral phase is seriously diminished and replaced by organic fluids. This is why we refer to "enamel hypomineralization". This defect in the enamel is due to modifications of the chemical composition of the substrate.

The laws of optics indicate that when there is a difference in refractive index between two phases, there will be an interface causing deviation of incident light rays.

The refractive index of healthy enamel is the same as that of hydroxapatite, which is, as explained above, by far the most important constituent of the phase $\left(\mathrm{RI}_{\text {healthy enamel }}=\right.$ $\mathrm{RI}_{\text {hydroxyapatite }}=1.62$ ). There are, therefore, hardly any interfaces in healthy enamel; the light ray passes through the substrate with no modification of its trajectory until it is reflected at the dentino-enamel junction ( $f$ ig. 1).

However, in hypomineralized enamel, the light ray encounters multiple interfaces between organic fluids and the mineral phase, with different indices of refraction (respectively 1.33 and 1.62). At each interface, the light is thus deviated and
- $\mathrm{MIH}$.

- Érosion-infiltration.

Le chirurgien dentiste, de par la demande esthétique croissante des patients, est au sein de son cabinet de plus en plus régulièrement confronté au traitement des anomalies de teinte des dents. L'absence de formation initiale claire dans ce domaine fait malheureusement que bien souvent leur diagnostic étiologique est perçu par le praticien comme une étape délicate. C'est sans doute ce qui explique que ce dernier opte préférentiellement pour l'abstention, ou parfois même pour l'éviction de la lésion par fraisage. Pourtant, actuellement il existe un arsenal thérapeutique " a minima " adapté associant l'éclaircissement, l'érosion-infiltration et/ou la micro-/ méga-abrasion. Seulement, avant de se décider pour l'une ou l'autre de ces thérapeutiques, il est impératif de connaître l'étiologie de la lésion. Dans le cadre de cet article, après avoir expliqué le mécanisme optique qui explique l'aspect blanchâtre des taches d'hypominéralisation amélaires, nous reprendrons une par une les différentes étiologies en décrivant précisément les lésions correspondantes, et les conséquences en termes de type de traitement et limites. Un second article sera consacré plus spécifiquement au traitement par érosion-infiltration de ces différentes taches.

\section{Un aspect blanc, un point commun : l'hypominéralisation}

La présence de tache blanche visible à la surface des dents résulte uniquement d'un défaut amélaire. Dans ce tableau clinique, la dentine n'est jamais mise en cause. L'émail sain, tissu le plus minéralisé de l'organisme, présente en poids $96 \%$ d'hydroxyapatite ; les $4 \%$ restants représentent les fluides organiques. Inversement, en présence de tache blanche, cette phase minérale se trouve fortement diminuée et remplacée par des fluides organiques. C'est pourquoi nous parlons d'« hypominéralisation amélaire ». Ce défaut d'émail est la conséquence d'une altération des taux de la composition chimique du substrat.

Les lois de l'optique indiquent que s'il existe une différence d'indice de réfraction entre deux phases, il y a apparition d'une interface provoquant la déviation du rayon incident.

Dans le cas de l'émail sain, son indice de réfraction est le même que celui de l'hydroxyapatite, phase largement majoritaire comme évoqué précédemment ( $\mathrm{IR}_{\text {émail sain }}=$ $I R_{\text {hydroxyapatite }}=1,62$ ). L'émail sain présente alors que peu d'interface ; le rayon lumineux traverse l'épaisseur du substrat sans modification de trajectoire, et ce jusqu'à la jonction amélo-dentinaire avant d'être réfléchie (fig. 1).

Tandis que dans le cas de l'émail hypominéralisé, le rayon lumineux rencontre de multiples interfaces " fluides organiques/minéral " d'indice de réfraction différent (respectivement 1,33 et 1,62), provoquées par leur alternance de phase. À chaque interface, le rayon est alors dévié et réfléchi, 
White defects on enamel: Diagnosis and anatomopathology: Two essential factors for proper treatment (part 1)

Taches blanches de l'émail : diagnostic et anatomopathologie : deux données indispensables pour bien les traiter (partie 1)
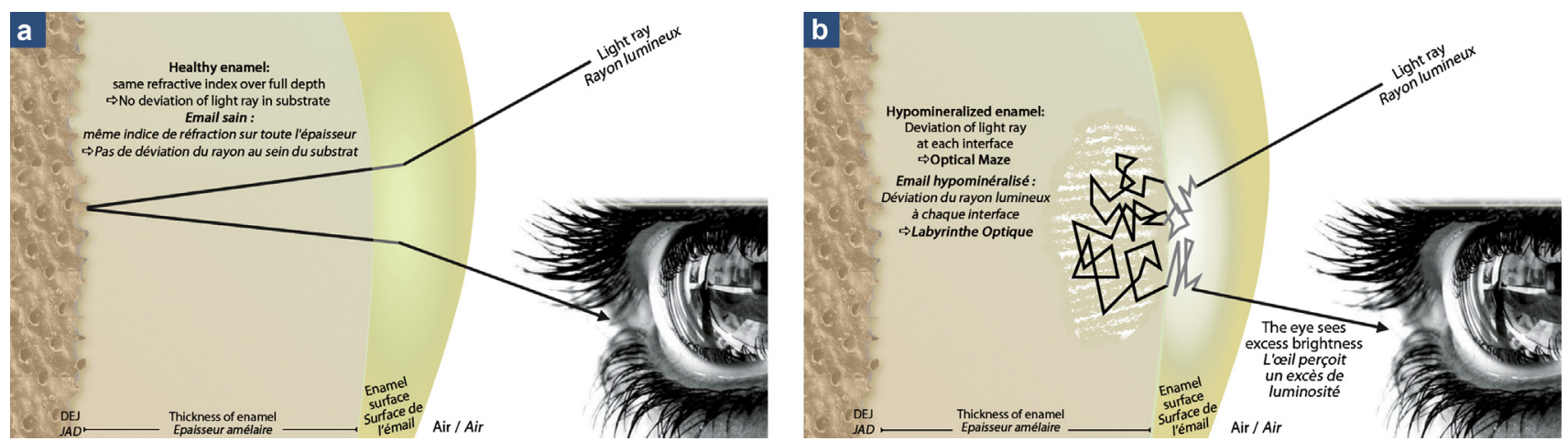

Fig. 1: Influence of laws of optics on perception of tooth color. a: on account of its composition, healthy enamel has a single refractive index corresponding to that of hydroxyapatite $\left(\mathrm{RI}_{\text {hydroxyapatite }}=1.62\right)$. Only the air/enamel and dentin/enamel junctions (DEJ: Dentino-Enamel Junction) are considered to be interfaces. Schematically, the light ray is refracted at the tooth surface then reflected by the DEJ, thus enabling the eye to perceive the color of the tooth; $\mathbf{b}$ : in hypomineralized enamel, the many changes of refractive index caused by fluid/hydroxyapatite phase transitions create interfaces within the enamel substrate. At each interface, the ray is deviated and reflected. The hypomineralized lesion forms an "optical maze" seen as white and opaque by the eye on account of the excess brightness.

Fig. 1 : Influence des règles optiques sur la perception de la teinte de la dent : a : l'émail sain de par sa composition a un indice de réfraction unique correspondant à celui de l'hydroxyapatite $\left(I_{\text {hydroxyapatite }}=1,62\right)$. Seules les jonctions air/émail et émail/dentine (JAD : jonction amélo-dentinaire) sont considérées comme des interfaces. Schématiquement, le rayon lumineux est réfracté à la surface de la dent puis réfléchi à la JAD permettant à l'œil de percevoir la teinte de la dent ; b : dans l'émail hypominéralisé, les multiples changements d'indice de réfraction provoqué par les changements de phase fluide/hydroxyapatite sont responsables de l'apparition d'interfaces au sein du substrat amélaire. À chaque interface, le rayon est dévié et réfléchi. La lésion hypominéralisée forme un « labyrinthe optique » perçu blanc/opaque par l'œil par excès de luminosité.

reflected, becoming imprisoned in an "optical maze" that is over-luminous and therefore perceived as white (fig. 1).

The "air blower test" can be used to confirm that it is indeed this difference in refractive index which is responsible for the white appearance of hypomineralized enamel. The defect appears even whiter when dried by the air blower simply because the organic fluids have been replaced by air, which has a still lower refractive index $\left(\mathrm{RI}_{\text {air }} \approx 1<\mathrm{RI}_{\text {organic }}\right.$ fluids $=1.33)$. Thus, by increasing the difference of refractive index compared with that of healthy enamel $\left(\mathrm{RI}_{\text {hydroxyapatite }}=1.62\right)$, the visibility of the defect is still further accentuated.

It is important to remember that, unlike enamel hypoplasia, in enamel hypomineralization there is no loss of substrate volume. Finally, therefore, the presence of a white area reveals the existence of underlying hypomineralization.

\section{The etiologies of enamel hypomineralization}

The alterations that explain the presence of areas of whitening are the consequences of post-eruptive or pre-eruptive damage. s'emprisonnant dans un « labyrinthe optique » trop lumineux, donc perçu blanc (fig. 1).

II est possible en utilisant le « test de la soufflette » de confirmer que c'est cette différence d'indice de réfraction qui est responsable de la perception blanche de l'émail hypominéralisé. Le défaut semble encore plus blanc lorsqu'il est séché par la soufflette du simple fait de substituer l'air aux fluides organiques, présentant un indice de réfraction encore inférieur à celui des fluides organiques $\left(I R_{\text {air }} \approx 1<I R_{\text {fluides organique }}=1,33\right)$. Ainsi, en augmentant la différence d'indice de réfraction par rapport à l'émail sain $\left(\mathrm{IR}_{\text {hydoxyapatite }}=1,62\right)$, la perception du défaut en devient encore plus accentuée.

Il est important de rappeler que lors d'une hypominéralisation amélaire, contrairement au cas d'une hypoplasie de l'émail, la totalité du volume du substrat est conservée. Finalement, la présence de tache blanche informe de l'existence sousjacente d'une hypominéralisation.

\section{Les étiologies des hypominéralisations amélaires}

Les altérations expliquant les taches blanches sont la conséquence d'atteintes post-éruptives ou pré-éruptives. 


\section{Post-eruptive damage: white spots}

The first stages of carious disease are characterized by hypomineralization without cavity formation. When this is clinically visible, we refer to it as white spots (WS).

\section{Prevalence}

It is important to note that WS are the most frequent pathologies responsible for areas of whitening, with an estimated prevalence of $24 \%$ [1]. This rises to $49.6 \%$ following multibracket orthodontic treatment, and the incidence of at least one non-cavitated lesion before/after orthodontic treatment is $72.9 \%$ [2]. Their treatment is all the more important in that it is the front teeth that are preferentially involved.

Moreover, this prevalence is multifocal: it concerns at least three teeth in $46 \%$ of patients not treated orthodontically, and rises to $77 \%$ in those who have received orthodontic treatment [3]. These white lesions reduce by one third at 3 months and by half at 6 months, but once present they remain, and are still visible 5 years after debonding.

The frequency of appearance of these elective post-eruptive lesions, and their long-lasting nature place the dentist under an obligation to take preventive measures and ensure early detection so that treatment is restricted to a necessary minimum.

\section{Diagnosis}

The diagnosis of the initial carious lesions is essentially a matter of clinical observation; at this stage, on account of the acellular, avascular and nerve-free nature of enamel, there are no associated symptoms. When these lesions reach the smooth surfaces of the front teeth, they are mainly found in the sites where bacterial plaque preferentially accumulates: either in the labial cervical third, or around the brackets in the event of orthodontic treatment. They are opaque, mat, chalky-white areas of enamel, variable in shape and size and with more or less clear-cut outlines (fig. 2a). The enamel surface is still continuous but possesses a certain degree of roughness, often associated with accentuation of micro-ridges (perikymata). To avoid the subjective element in visual observation of the initial carious lesion, the "International Caries Detection and Assessment System" (ICDAS) suggested by Ekstrand (Table I) [4] is used; this also provides information on histological involvement. Early detection tools (quantitative laser fluorescence [Diagnodent ${ }^{\circledR}$ ], Fibre Optic Transillumination [FOTI], etc.) can also be important aids for their evaluation. The dentist should support clinical observation by weighing up the risk factors (direct, environmental and individual) listed by Selwitz [5] that may be involved in the development of caries so as to confirm the diagnosis and subsequently restore an environment favorable to oral health.
Atteinte post-éruptive : white spots (WS)

Les premiers temps de la maladie carieuse se traduisent par une hypominéralisation non cavitaire. Lorsqu'elle est cliniquement visible, nous l'appelons white spots (WS).

\section{Prévalence}

II est important de noter que la prévalence des WS est la plus importante de toutes les pathologies responsables de tache blanche. Elle est estimée à $24 \%$ [1]. Elle passe à 49,6\% à l'issu d'un traitement orthodontique par multi-attaches, avec une incidence d'au moins une lésion non cavitaire avant/après traitement orthodontique de $72,9 \%$ [2]. II est d'autant plus nécessaire de les prendre en charge que l'atteinte des dents du sourire est préférentielle.

De plus, elle est multifocale ; elle concerne au moins trois dents chez $46 \%$ des patients non traités orthodontiquement et passe à $77 \%$ chez ceux ayant reçu un traitement orthodontique [3]. Une fois installées, même si ces lésions blanches se réduisent d'un tiers à trois mois et de la moitié à six mois, elles apparaissent encore visible cinq ans après dépose de l'appareillage.

La fréquence d'apparition de ces lésions électives postéruptive associée à leur pérennité, confère au praticien un devoir de prophylaxie et de détection précoce permettant l'instauration d'« intervention minimale ».

\section{Diagnostic}

Le diagnostic des lésions carieuses initiales est principalement permis par l'observation clinique; à ce stade étant donné le caractère acellulaire, avasculaire, non innervé de l'émail, aucune symptomatologie n'y est associée. Lorsqu'elles atteignent les surfaces lisses des dents antérieures, elles sont principalement retrouvées en regard des sites de prédilection de dépôts de plaque bactérienne ; soit dans le tiers cervical vestibulaire, soit autour des attaches lors d'un traitement orthodontique. Elles présentent alors une zone d'émail mate-opaque, blanc crayeux, de taille et de forme variables dont les contours sont plus ou moins diffus (fig. 2a). L'émail de surface encore continu présente une certaine rugosité souvent accompagnée d'une accentuation des microreliefs (périkymaties). Pour éviter le caractère subjectif de l'observation visuelle d'une lésion carieuse initiale, le "Système international de détection et d'évaluation de la carie » (ICDAS) proposé par Ekstrand (Tableau I) [4], informant simultanément de l'atteinte histologique, est utilisé. Les outils de détection précoce (fluorescence laser quantitative [Diagnodent ${ }^{\circledR}$ ], transillumination par fibres optiques [FOTI], etc.) peuvent aussi être des atouts importants dans leur évaluation. Le praticien complète l'observation clinique par la pondération des facteurs de risques (directs, environnementaux et personnels) présentés par Selwitz [5] pouvant être impliqués dans le développement carieux, afin de certifier le 
White defects on enamel: Diagnosis and anatomopathology: Two essential factors for proper treatment (part 1) Taches blanches de l'émail : diagnostic et anatomopathologie : deux données indispensables pour bien les traiter (partie 1)
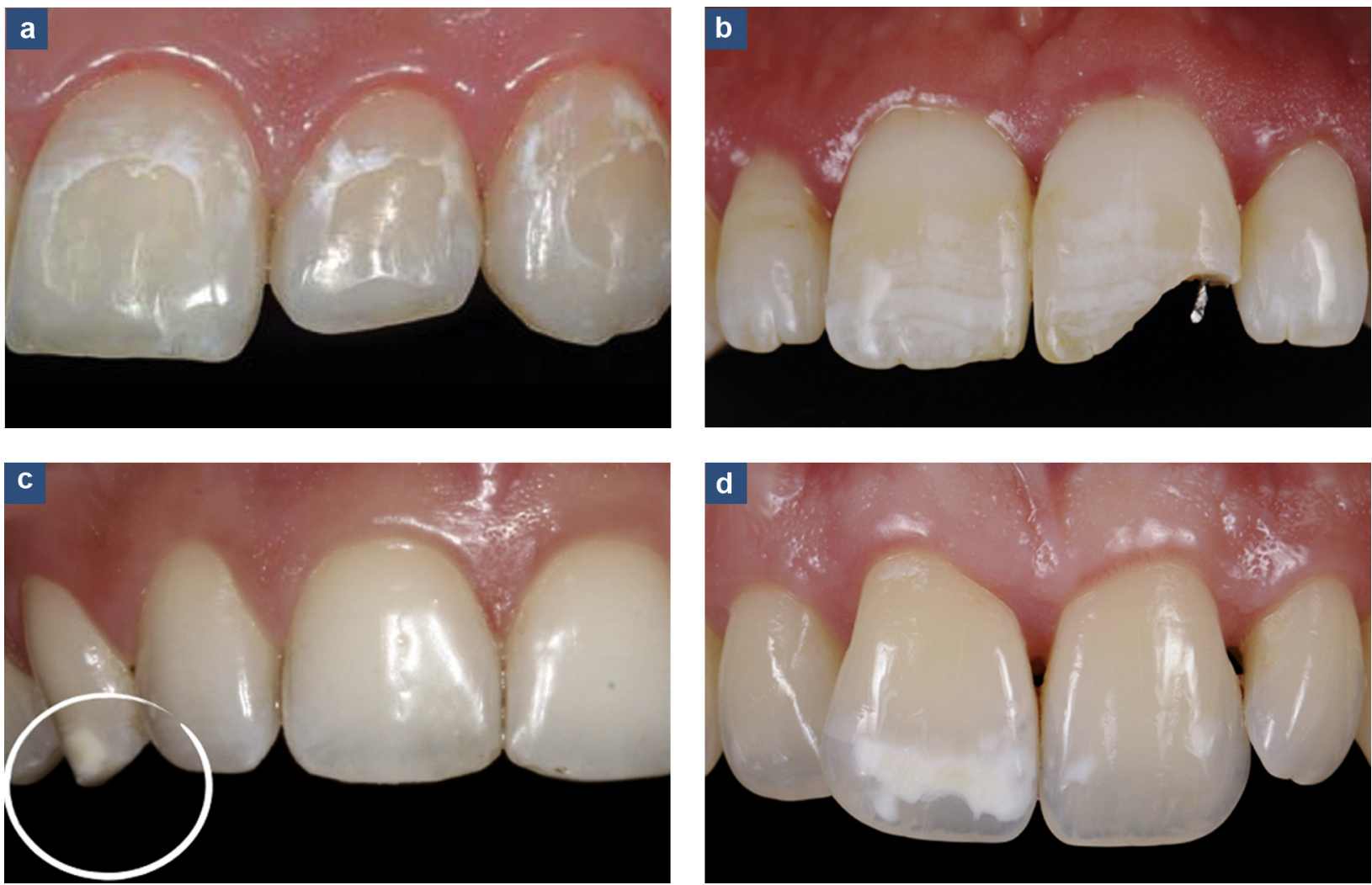

Fig. 2: Clinical appearances characteristic of the various etiologies involved in the presence of white defects on the enamel; a: white spot. The localization of hypomineralization can correspond to a zone where bacterial plaque preferentially accumulates; here following multi-bracket orthodontic treatment. It appears chalky-white, mat, opaque, with variable shape and size and outlines that are more or less well-defined; b: fluorosis. Symmetrical involvement of groups of homologous teeth. In the early stages, it is revealed by the presence of horizontal, more or less convergent white lines, accompanied or not by cloudy chalky areas that give the tooth a parchmentlike appearance. Loss of substance is always the consequence of post-eruptive weakening of the crystalline lattice; c: traumatic hypomineralization. Although many clinical expressions are possible, it is generally punctiform, located on the incisal coronal third of one or several neighboring teeth; d: MIH. In the "mild" form, lesions of molars and/or incisors take the form of well-defined opaque white areas, limited to the occlusal half of the tooth crown. Opacities on homologous teeth are asymmetrical.

Fig. 2 : Aspects cliniques caractéristiques des différentes étiologies en cause dans la présence de tache blanche de l'émail : a : white spot. La localisation de l'hypominéralisation est à rapprocher avec une zone préférentielle d'accumulation de plaque bactérienne ; ici suite au port d'un appareillage orthodontique par multi-attache. Elle revêt un aspect mate-opaque, blanc crayeux, de taille et de forme variables dont les contours sont plus ou moins diffus ; b : fluorose. L'atteinte est symétrique sur les groupes de dents homologues. Elle se traduit dans les premiers stades par la présence de lignes blanches horizontales \pm confluentes, accompagnées ou non de zones nuageuses crayeuses conférant à la dent un aspect parcheminé. La perte de substance est toujours consécutive à un affaiblissement post-éruptif de la trame cristalline ; c : l'hypominéralisation traumatique. Malgré sa grande variété d'expression clinique, elle est généralement ponctiforme, située sur le tiers incisale coronaire d'un ou plusieurs dents voisine ; $d$ : MIH. L'atteinte des molaires et/ ou incisives présente, à un stade " léger ", des opacités blanches bien délimitées, circonscrites à la moitié occlusale de la couronne. Les opacités sont asymétriques sur les dents homologues.

\section{Anatomopathology}

During the initial carious process, alternating phases of demineralization and remineralization cause preferential dissolution and reprecipitation and, thereby, the preservation of a diagnostic et de rétablir ultérieurement un environnement en adéquation avec la santé buccale.

\section{Anatomopathologie}

Lors du processus carieux initial, l'alternance de phase de déminéralisation/reminéralisation permet par dissolution/ reprécipitation préférentielles la préservation d'une « couche 


\section{Table I}

Classification of carious lesions according to the ICDAS proposed by Ekstrand (caries Res, 1997).
Tableau I

Classification des lésions carieuses selon l'ICDAS proposé par Ekstrand (Caries Res, 1997).

\begin{tabular}{lll}
\hline Score & Clinical criteria/Critères cliniques & Histology/Histologie \\
\hline 0 & $\begin{array}{l}\text { Absence of, or slight change in, enamel } \\
\text { translucidity after prolonged drying }(>5 \mathrm{~s}) /\end{array}$ & No clear-cut demineralization/Pas de \\
& $\begin{array}{l}\text { Absence ou léger changement de la translucidité } \\
\text { de l'émail après séchage prolongé }(>5 \mathrm{~s})\end{array}$ & \\
\hline 1 & $\begin{array}{l}\text { Opacity or scarcely visible discoloring on wet } \\
\text { surface but visually distinct after drying/Opacité ou } \\
\text { discoloration difficilement visible au niveau d'une } \\
\text { surface humide, mais distinguée visiblement après } \\
\text { séchage }\end{array}$ & $\begin{array}{l}\text { Demineralization limited to the external half of the } \\
\text { enamel/Déminéralisation limitée à la moitié externe } \\
\text { de l'émail }\end{array}$ \\
\hline 2 & $\begin{array}{l}\text { Opacity or discoloring clearly visible after drying/ } \\
\text { Opacité ou discoloration nettement visible après } \\
\text { séchage }\end{array}$ & $\begin{array}{l}\text { Demineralization as far as the median third of the } \\
\text { enamel/Déminéralisation allant jusqu'au tiers } \\
\text { médian de l'émail }\end{array}$ \\
\hline 3 & $\begin{array}{l}\text { Presence of an enamel cavity in colored opaque } \\
\text { enamel and/or greyish discoloring of the underlying } \\
\text { dentin/Présence d'une cavité amélaire au niveau } \\
\text { d'un émail opaque coloré et/ou discoloration } \\
\text { grisâtre de la dentine sous-jacente }\end{array}$ & $\begin{array}{l}\text { Demineralization as far as the internal third of the } \\
\text { enamel. The dentin can also be affected/ } \\
\text { Déminéralisation allant jusqu'au tiers interne de } \\
\text { l'émail, et la dentine peut être affectée }\end{array}$ \\
\hline $\begin{array}{l}\text { Cavity in opaque or discolored enamel exposing the } \\
\text { dentin/Cavité au niveau de l'émail opaque ou } \\
\text { décoloré exposant la dentine }\end{array}$ & $\begin{array}{l}\text { The entire thickness of the enamel is involved and } \\
\text { the dentin is infected/La totalité de l'épaisseur de } \\
\text { l'émail est atteinte, et la dentine est infectée }\end{array}$ \\
\hline
\end{tabular}

ICDAS: The International Caries Detection and Assessment System. White spots relate only to score 2 .

ICDAS : The International Caries Detection and Assessment System (Système international de détection et d'évaluation de la carie). La notion de white spot ne concerne que le score 2.

relatively intact "surface layer", under which the body of the carious lesion extends in half-moon shape (or the so-called "cone shape") to the "demineralization front" (fig. 3a) [6]. This histological organization has been perfectly described by Silverstone [7] and reviewed by Kaqueler [8].

Caries cause the crystalline structures to be dissolved along the weak points in the enamel (fig. 3b) [9]; that is longitudinally along the prisms and laterally along the striae of Retzius, thus creating broad channels of communication directly accessible from the external environment. Hypomineralization of the subsurface of WS gives rise to enlargement of the initial pores in the enamel (fig. 3c) [10], maintaining a crystalline scaffold that is sparser but still present. The preservation of this scaffold, even when mineral dissolution has significantly progressed, is possible thanks to the bonding of apatite crystals to an acid-tolerant protein sheath acquired during amelogenesis [11]. The lesion becomes clinically visible when the mineral deficit of the body of the lesion compared to healthy enamel reaches $10 \%$. At an advanced stage, it can rise to more than $40 \%$. superficielle » relativement intacte sous laquelle s'étend le " corps de la lésion carieuse » en forme en demi-lune (ou dite « en cône ») jusqu'au « front de déminéralisation » (fig. 3a) [6]. Cette organisation histologique a été parfaitement décrite par Silverstone [7] puis revue par Kaqueler [8].

La dissolution cristalline consécutive à la maladie carieuse progresse le long des points de faiblesse de l'émail (fig. 3b) [9] ; c'est-à-dire en longueur le long des prismes et en largeur le long des stries de Retzius, provoquant ainsi de larges chéneaux de communication directement accessibles depuis le milieu extérieur. L'hypominéralisation de subsurface des WS se traduit par un élargissement des porosités initiales de l'émail (fig. 3c) [10] maintenant un échafaudage cristallin amoindri mais présent. La préservation de cet échafaudage, même à un stade avancé de dissolution minérale, est permise par la liaison des cristaux d'apatite à une gaine protéique tolérante aux acides acquis durant l'amélogenèse [11]. La lésion devient cliniquement visible lorsque le corps de la lésion accuse un déficit minéral de $10 \%$ par rapport à l'émail sain. II peut, à un stade avancé, aller jusqu'à plus de $40 \%$. 
White defects on enamel: Diagnosis and anatomopathology: Two essential factors for proper treatment (part 1) Taches blanches de l'émail : diagnostic et anatomopathologie : deux données indispensables pour bien les traiter (partie 1)
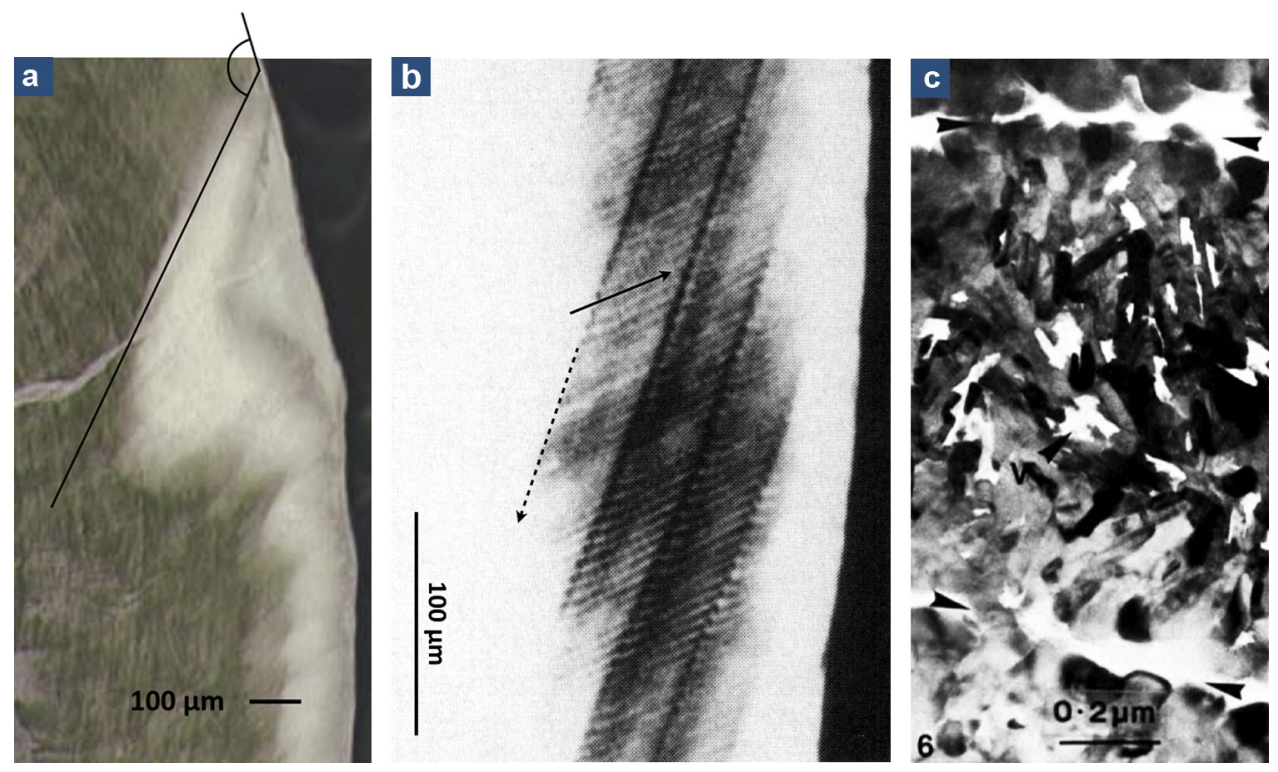

Fig. 3: Anatomopathological characteristics of a white spot as seen on a transverse cross-section: a: observed with optical microscope (from Kielbassa). The lesion extends from the surface of the tooth to the demineralization front at an obtuse angle. White spot hypomineralization remains subsurface with no alteration of the volume of enamel; b: observed with microradiography (from Pearce). The surface layer remains relatively intact. Dissolution of crystals proceeds along lines of weakness (enamel prisms [solid arrow] and striae of Retzius [dotted arrow]), creating broad channels of communication; c: observed with transmission electron microscope $(\times 85,000)$ (from Palamara). Inter- (black arrows) and intra-prismatic micropores are notably enlarged.

Fig. 3 : Les caractéristiques anatomopathologiques d'un white spot à partir de section transversale : a : observé au microscope optique (d'après Kielbassa). La lésion s'étend depuis la surface de la dent jusqu'au front de déminéralisation selon un angle obtus. L'hypominéralisation des white spot est de subsurface sans altération du volume de l'émail ; b : observé par microradiographie (d'après Pearce). La couche de surface reste relativement intacte. La dissolution cristalline progresse le long des points de faiblesse (prismes d'émail [flèche continue] et des stries de Retzius [flèche pointillée]) créant de larges chéneaux de communication ; c : observé par microscopie à transmission ( $\times 85000)$ (d'après Palamara). Les porosités inter-prismes (flèches noires) et intra-prismatiques sont fortement augmentées.

\section{Treatment}

The association of the diagnosis of WS with this histopathological data makes it possible to propose "conservative" treatment corresponding to different stages of severity (Table I) (fig. 4).

For lesions with an ICDAS score of 0 or 1 , with only slight subsurface hypomineralization, crystalline reprecipitation sufficient to restore a normal enamel substrate may be obtained with fluoride or caseine phosphopeptide treatment.

However, for ICDAS level 2 lesions, remineralization treatments cannot guarantee reprecipitation over the whole depth of the lesion. Although they can ensure bacterial control and surface strengthening, the internal part of the body of the lesion, with its microporosities, remains in existence. This is

\section{Traitement}

L'association du diagnostic de WS à ces données histopathologiques permet de proposer des traitements « conservateurs » adaptés aux différents degrés de gravité (Tableau I) (fig. 4).

Lors de lésions de score 0 à 1 (ICDAS) où l'hypominéralisation de subsurface est faible, il est possible avec des traitements de fluorures ou de phosphopeptides de caséine d'entreprendre une reprécipitation cristalline adéquate avec le retour à la normalité du substrat amélaire.

En revanche, lors de lésions de score 2 (ICDAS), les thérapeutiques de reminéralisation ne parviennent pas à assurer une reprécipitation sur toute la profondeur de la lésion. Bien qu'elles assurent un contrôle bactérien et un renforcement de surface, la partie interne du corps de la lésion avec ses 


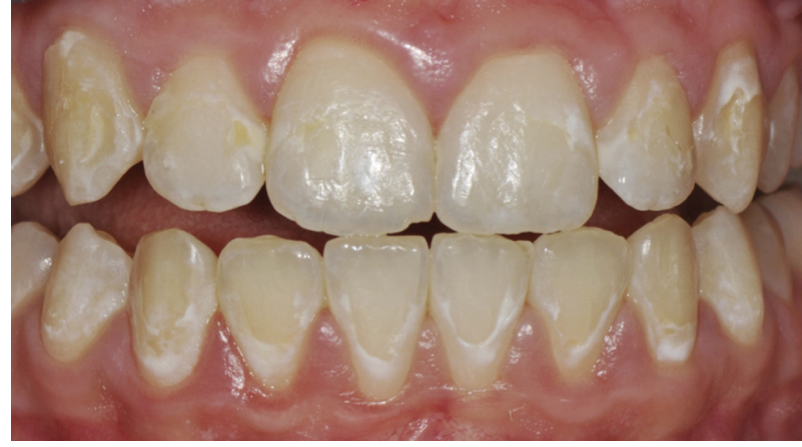

Fig. 4: What treatment for different stages of early carious lesions? Following orthodontic treatment, the patient presents carious lesions with ICDAS scores of 1,2 and 3 . Only scores 2 and 3 are visible on this photo of teeth without air-drying. The loss of substance associated with score-3 lesions of 13, 12, 22 and 23 is the result of excessive mechanical action. The dentin is not involved. At this stage, topical application alone of a remineralizing product will not lead to disappearance of the defects in the enamel despite a return to a healthy state. Only conservative treatment by "erosion-infiltration" can halt the progression of crystal dissolution by creating an impermeable barrier, and also restore tooth color.

Fig. 4 : Quels traitements pour quel niveau d'atteinte de lésions carieuses initiales ? Le patient présente à l'issu d'un traitement orthodontique des lésions carieuses de score ICDAS 1, 2 et 3. Seules les scores 2 et 3 sont visibles sur cette photo de dents non séchées. Les pertes de substances des lésions de score 3 des 13 , 12,22 et 23 sont consécutives à une action mécanique excessive. La dentine n'est pas mise en cause. À ce degré d'atteinte, l'application topique seule de produit reminéralisant ne permettra pas la disparition des défauts amélaires malgré un retour à l'état de santé. Seule, l'application d'une thérapeutique conservatrice par "érosion-infiltration " stoppera la progression de la dissolution cristalline par imperméabilisation, tout en restaurant la teinte des dents. why, despite perfect etiological control, the white area persists over time, and brown coloring may even appear following progressive micro-infiltration by extrinsic pigments (fig. 5). Today, for these score 2 lesions, the only genuine "minimally invasive" treatment available on the market, to both arrest the caries and restore good esthetics, is "erosion-infiltration". The only product currently marketed that corresponds to this principle is Icon (DMG). First of all, it uses hydrochloric acid to eliminate the relatively intact surface layer and open up access to the body of the lesion. Then, in a second stage, a fluid resin is infiltrated into the broad channels of communication. The body of the lesion is rendered watertight by means of a resin with a refractive index $\left(\mathrm{IR}_{\mathrm{i}-\mathrm{con}}{ }^{\circledR}=1.44\right)$ close to that of healthy enamel, so as to both stop the diffusion of acids, thus halting progression of the caries, and mask the discolorations by optical means [12]. microporosités continue de persister. C'est ce qui explique, malgré un parfait contrôle étiologique, la conservation à long terme de la tache blanche, voire même l'apparition de coloration brune suite à la micro-infiltration progressive de colorants extrinsèques (fig. 5). Aujourd'hui, pour ces lésions de score 2, le seul traitement véritablement « a minima » disponible sur le marché, assurant à la fois l'arrêt de la maladie carieuse et le rétablissement de l'esthétique, est l' « érosion-infiltration ». Le seul produit commercialisé actuellement qui répond à ce principe s'appelle Icon (DMG). II élimine dans un premier temps par un traitement à l'acide chlorhydrique la couche de surface relativement intacte. C'est ce qui permet d'ouvrir l'accès au corps de la lésion et, dans un second temps, d'infiltrer avec une résine fluide ses larges chéneaux de communication. L'imperméabilisation du corps de la lésion avec une résine d'indice de réfraction $\left(\mathrm{IR}_{\mathrm{i}-\mathrm{con}}{ }^{\circledR}=1,44\right)$ proche de l'émail sain, 
White defects on enamel: Diagnosis and anatomopathology: Two essential factors for proper treatment (part 1)

Taches blanches de l'émail : diagnostic et anatomopathologie : deux données indispensables pour bien les traiter (partie 1)

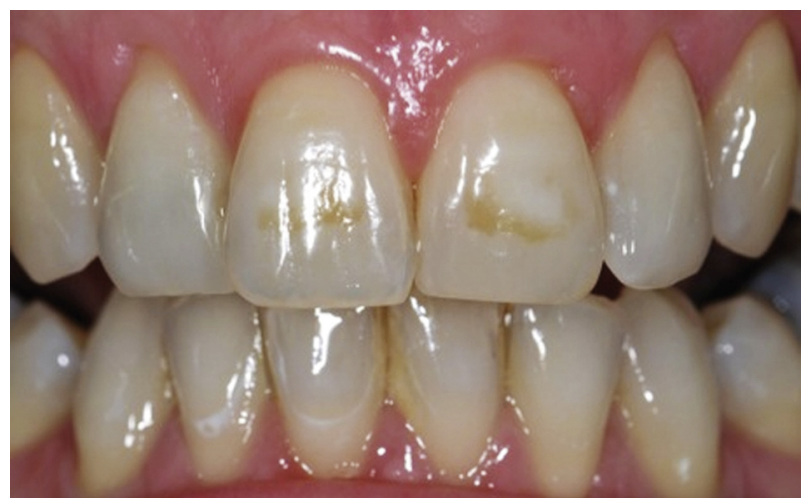

Fig. 5: Post-orthodontic WS (ICDAS 2) treated solely by topical fluorination. Despite good plaque control and halting of the dental caries, this partial remineralization has not made it possible to restore natural tooth color. There is still a creamy-white cloud on the central incisors surrounded by a colored halo that appeared after remineralization due to continuing infiltration of extrinsic pigments.

Fig. 5 : WS (ICDAS 2) post-orthodontique traitées uniquement par fluoration topique. Malgré le retour à un bon contrôle de plaque et un arrêt de la maladie carieuse, la reminéralisation partielle n'a pas permis de récupérer la teinte naturelle des dents. Sur les incisives centrales persiste un nuage blanc crème entouré d'un halot coloré apparu suite à la poursuite, post-reminéralisation, d'infiltration de colorants extrinsèques.

\section{Pre-eruptive lesions: fluorosis, traumatic hypomineralization, MIH}

\section{Fluorosis}

By definition, "fluorosis is a hypomineralization of the enamel caused by excessive incorporation of fluorides during its formation" [13].

\section{Prevalence}

The combination of excessive consumption of fluorinated food products and/or supplements at the instigation of over-conscientious parents, along with lack of information on the problems this may lead to, means that although the last major French epidemiological study on the prevalence of dental fluorosis seemed reassuring (in 1999 only $2.75 \%$ [14] of children scored 2 to 4 on the Tylstrup and Fejerskov scale), a sharp increase in this figure can be expected in the years to come. The US National Institute of Dental Research had already noted an increase of $9 \%$ in cases of fluorosis over 15 years (1986-2002). permet à la fois de stopper la diffusion des acides, donc la progression de la maladie carieuse, et de masquer par phénomène optique ces stigmates [12].

\section{Atteinte pré-éruptive : la fluorose, I’hypominéralisation traumatique, le $\mathrm{MIH}$}

\section{La fluorose}

Par définition « la fluorose est une hypominéralisation de l'émail liée à une incorporation trop importante de fluorures lors de sa formation » [13].

\section{Prévalence}

La surconsommation de produits et/ou compléments alimentaires fluorés instaurée par des parents trop prudents, associée à la sous-information des problèmes qu'elle entraîne, fait que même si la dernière grande étude épidémiologique française sur la prévalence des fluoroses dentaire paraissait rassurante (en 1999, seulement 2,75\% [14] des enfants avaient une fluorose de grade 2 à 4 de l'index de Tylstrup et Fejerskov), il faut s'attendre, dans les années à venir, à constater une nette augmentation de ce chiffre. L'Institut national de recherche dentaire des États-Unis avait 


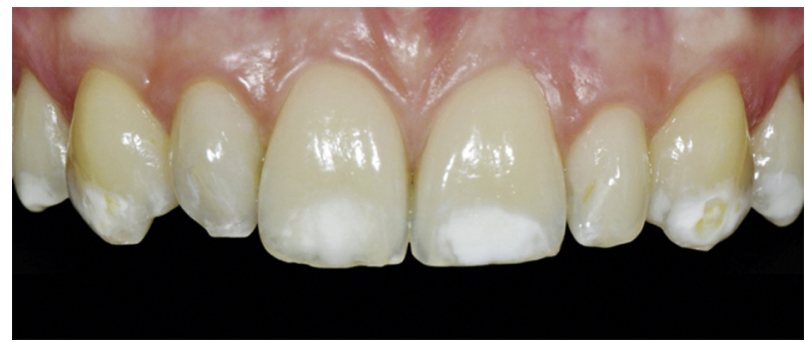

Fig. 6: Dental repercussions of systemic fluoride intoxication. Fuorotic lesions are TSIF stage 1 (Table III). Data concerning the kinetics of mineralization of tooth germs (Table II) suggest in this case chronic systemic intoxication by fluorides from the age of 3 months to $2^{1} / 2$ years approximately. The clinical consequences are symmetrical on groups of homologous teeth.

Fig. 6 : Répercussion dentaire d'une intoxication systémique aux fluorures. L'atteinte fluorotique est au stade 1 TSIF (Tableau III). La connaissance de la cinétique de minéralisation des germes dentaires (Tableau II) permet, ici, d'incriminer une intoxication systémique chronique aux fluorures de l'âge de trois mois à deux ans et demi environ. Les conséquences cliniques sont symétriques sur les groupes de dents homologues.

\section{Diagnosis}

The diagnosis of fluorosis is significantly delayed with respect to the period of intoxication since it is based on clinical observation of the adult teeth following their eruption. The main characteristic of the abnormalities noted in the enamel is the symmetrical involvement of homologous teeth and often the involvement of several groups of teeth. This is the main criterion for systemic intoxication (fig. 6). According to the type of tooth concerned and the level of abnormalities on the crown, a presumptive dating can be determined for the period of intoxication (Table II: table of coronal mineralization [15]).

Several classifications based on the degree of severity have been proposed (Dean's Index, Tylstrup and Fejerskov scoring system, Horowitz's Tooth Surface Index of Fluorosis [TSIF]). All are still in use today. The Horowitz classification (Table III) usefully associates the extent of coronal involvement and its clinical appearance. This classification will be used as a reference.

The problem of fluorotic WS, with intact surface enamel, concerns only the less severe stages of the disease (TSIF 1 to 4) (fig. 6-9), which is then revealed by the presence of more or less convergent horizontal white lines (fig. 2b), which may or may not be accompanied by irregular chalky zones giving the tooth a parchment-like appearance. These discolorations appear after tooth eruption through infiltration of exogenous de son côté déjà relevé une augmentation de $9 \%$ des cas de fluorose en 15 ans (1986-2002).

\section{Diagnostic}

Le diagnostic de fluorose intervient tardivement par rapport à la période d'intoxication puisqu'il se base sur l'observation clinique de la denture définitive à la suite de son éruption. L'anomalie de structure de l'émail qui est observée, a la caractéristique principale de provoquer des atteintes symétriques des dents homologues et bien souvent généralisées à plusieurs groupes de dents. C'est le critère principal d'une intoxication systémique (fig. 6). Suivant le type de dent et le niveau coronaire atteints, il est possible de façon présomptive de dater la période d'intoxication (Tableau II : table de minéralisation coronaire [15]).

Plusieurs classifications selon le degré de gravité ont été proposées (index de Dean, index de Tylstrup et Fejerskov, index de surface de la fluorose dentaire [TSIF] d'Horowitz). Elle sont aujourd'hui encore toutes utilisées. La classification d'Horowitz (Tableau III) présente l'intérêt d'associer l'étendue de l'atteinte coronaire à l'aspect clinique qu'elle présente. Cette classification nous sert de référence.

La problématique des taches blanches fluorotiques où l'émail de surface est conservé, concerne uniquement les stades les moins sévères de la pathologie (TSIF 1 à 4) (fig. 6-9). Elle se traduit alors par la présence de lignes blanches horizontales plus ou moins confluentes (fig. 2b), accompagnées ou non de zones nuageuses crayeuses conférant à la dent un aspect parcheminé. Les colorations apparaissent de façons post- 


\section{Table II}

Crown mineralization table.
Tableau II

Table de minéralisation coronaire.

\begin{tabular}{|c|c|c|c|c|c|c|c|c|}
\hline & $\begin{array}{l}\text { Central } \\
\text { incisor/Incisive } \\
\text { centrale }\end{array}$ & $\begin{array}{l}\text { Lateral incisor/ } \\
\text { Incisive } \\
\text { latérale }\end{array}$ & $\begin{array}{l}\text { Canine/ } \\
\text { Canine }\end{array}$ & $\begin{array}{l}\text { First } \\
\text { premolar/ } \\
\text { Première } \\
\text { prémolaire }\end{array}$ & $\begin{array}{l}\text { Second } \\
\text { premolar/ } \\
\text { Seconde } \\
\text { prémolaire }\end{array}$ & $\begin{array}{l}\text { First molar/ } \\
\text { Première } \\
\text { molaire }\end{array}$ & $\begin{array}{l}\text { Second } \\
\text { molar/ } \\
\text { Deuxième } \\
\text { molaire }\end{array}$ & $\begin{array}{l}\text { Third molar/ } \\
\text { Troisième } \\
\text { molaire }\end{array}$ \\
\hline $\begin{array}{l}\text { Initial mineralisation/ } \\
\text { Début de minéralisation }\end{array}$ & $\begin{array}{l}3 \text { months } / 3 \\
\text { mois }\end{array}$ & $\begin{array}{l}6 \text { months } / 6 \\
\text { mois }\end{array}$ & $\begin{array}{l}6 \text { to } \\
9 \text { months } / 6 \\
\text { à } 9 \text { mois }\end{array}$ & $2 \mathrm{yrs} / 2$ ans & $3 \mathrm{yrs} / 3$ ans & $\begin{array}{l}\text { Birth/ } \\
\text { Naissance }\end{array}$ & $\begin{array}{l}21 / 2 \text { yrs/ } \\
21 / 2 \text { ans }\end{array}$ & $\begin{array}{l}7 \text { to } 10 \mathrm{yrs} / 7 \\
\text { à } 10 \text { ans }\end{array}$ \\
\hline $\begin{array}{l}\text { Crown completed/ } \\
\text { Achèvement } \\
\text { de la couronne }\end{array}$ & $\begin{array}{l}4 \text { to } 5 \mathrm{yrs} / 4 \text { à } \\
5 \text { ans }\end{array}$ & $5 \mathrm{yrs} / 5$ ans & $6 \mathrm{yrs} / 6$ ans & $\begin{array}{l}6 \text { to } 7 \text { yrs } / 6 \text { à } \\
7 \text { ans }\end{array}$ & $\begin{array}{l}6 \text { to } 8 \text { yrs } / 6 \text { à } \\
8 \text { ans }\end{array}$ & $\begin{array}{l}3 \text { to } 4 \mathrm{yrs} / 3 \text { à } \\
4 \text { ans }\end{array}$ & $8 \mathrm{yrs} / 8$ ans & $\begin{array}{l}13 \text { to } 15 \mathrm{yrs} / \\
13 \text { à } 15 \text { ans }\end{array}$ \\
\hline Eruption/Éruption & $\begin{array}{l}6 \text { to } 7 \text { yrs } / 6 \text { à } \\
7 \text { ans }\end{array}$ & $\begin{array}{l}7 \text { to } 8 \text { yrs } / 7 \text { à } \\
8 \text { ans }\end{array}$ & $\begin{array}{l}11 \text { to } 12 \mathrm{yrs} / \\
11 \text { à } 12 \text { ans }\end{array}$ & $\begin{array}{l}10 \text { to } 12 \mathrm{yrs} / \\
10 \text { à } 12 \text { ans }\end{array}$ & $\begin{array}{l}11 \text { to } 12 \mathrm{yrs} / 11 \\
\text { à } 12 \text { ans }\end{array}$ & $6 \mathrm{yrs} / 6$ ans & $\begin{array}{l}12 \text { to } 13 \mathrm{yrs} / \\
12 \text { à } 13 \text { ans }\end{array}$ & $\begin{array}{l}17 \text { yrs and } \\
+/ 17 \text { ans et } \\
+\end{array}$ \\
\hline
\end{tabular}

From Fortier and Demars 


\section{Table III}

Horowitz index of Dental Fluorosis Surfaces (TSIF).
Tableau III

Index de surface de la fluorose dentaire (TSIF) d'Horowitz.

\begin{tabular}{ll}
\hline Stage/Stade & Clinical criteria/Critères cliniques \\
\hline 0 & No sign of fluorosis/Aucune évidence de fluorose \\
\hline 1 & $\begin{array}{l}\text { Fluorosis is limited to the cusp tips with a snowy-white occlusal cap on the molars/La fluorose est limitée } \\
\text { au sommet des cuspides, avec une coiffe neigeuse occlusale pour les molaires }\end{array}$ \\
\hline 3 & $\begin{array}{l}\text { White parchment-like appearance on less than } 2 / 3 \text { of the enamel surface/Aspect en parchemin blanc sur } \\
\text { moins de } 2 / 3 \text { de la surface amélaire }\end{array}$ \\
\hline 4 & $\begin{array}{l}\text { White parchment-like appearance on at least } 2 / 3 \text { of the enamel surface/Aspect en parchemin blanc sur au } \\
\text { moins } 2 / 3 \text { de la surface amélaire }\end{array}$ \\
\hline 5 & $\begin{array}{l}\text { Discolored areas with patches ranging from very pale to dark brown/Aires de décoloration avec des plages } \\
\text { allant du très clair au marron sombre }\end{array}$ \\
\hline 6 & Slight stippling with discoloring of pits/Piqueté discret avec coloration des puits \\
\hline 7 & Slight stippling with change of enamel color/Piqueté discret et changement de couleur de l'émail \\
\hline & $\begin{array}{l}\text { Pits merge forming wide areas of dark brown enamel alongside areas where the enamel is no longer present/ } \\
\text { Confluence des puits formant de larges plages d'émail brun sombre, coexistant avec des plages où l'émail }\end{array}$ \\
\hline
\end{tabular}

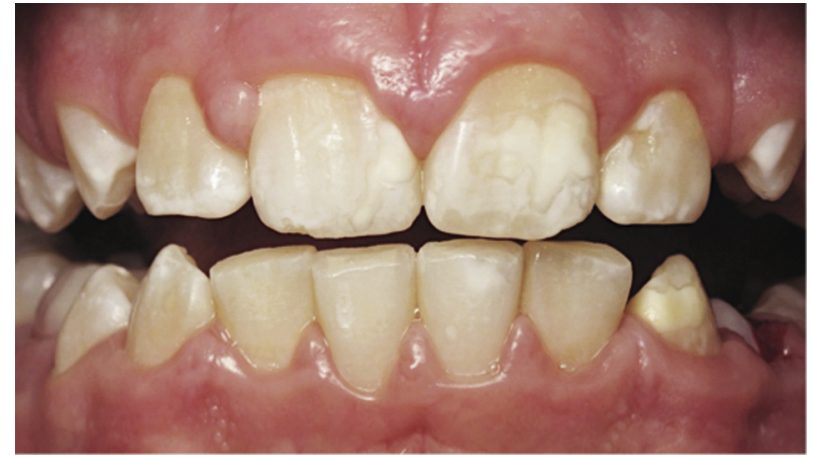

Fig. 7: TSIF stage 2 fluorosis (courtesy of Dr Etrillard). The white parchment appearance extends over two third of the enamel surface of the upper incisors and canines.

Fig. 7 : Fluorose de stade 2 TSIF (courtoisie du Dr Etrillard). L'aspect de parchemin blanc s'étend sur deux tiers de la surface amélaire des incisives maxillaires et des canines.

pigments (fig. 9). At more advanced stages (TSIF $>4$ ), the fluorotic enamel is physically and chemically attacked by substances in the mouth and partially cracks, causing secondary modifications to its surface texture (pitting and fissures).

\section{Anatomopathology}

Histopathological data show that teeth suffering from dental fluorosis $(\mathrm{TSIF} \leq 4)$ have a hypermineralized surface layer and subsurface hypomineralization involving the external third of the thickness of the enamel (fig. 10) [16]. The éruptives suite à l'infiltration de colorants exogènes (fig. 9). À des degrés plus avancés (TSIF $>4$ ), l'émail fluorotique se fracture partiellement face aux agressions physiques et chimiques endo-buccales provoquant une altération secondaire du relief de surface (puits et fissures).

\section{Anatomopathologie}

Les données histopathologies indiquent que les dents porteuses de fluorose dentaire (TSIF $\leq 4)$ présentent, sous une couche de surface hyperminéralisée, une hypominéralisation de subsurface impliquant le tiers externe de l'épaisseur de 
White defects on enamel: Diagnosis and anatomopathology: Two essential factors for proper treatment (part 1) Taches blanches de l'émail : diagnostic et anatomopathologie : deux données indispensables pour bien les traiter (partie 1)

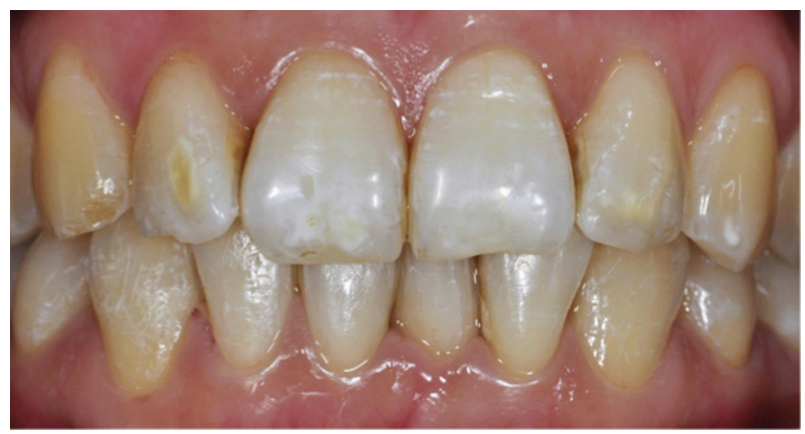

Fig. 8: TSIF stage 3 fluorosis. The white parchment appearance extends over the whole of the enamel surface of the upper central incisors.

Fig. 8 : Fluorose de stade 3 TSIF. L'aspect de parchemin blanc s'étend sur la totalité de la surface amélaire des incisives centrales maxillaires.

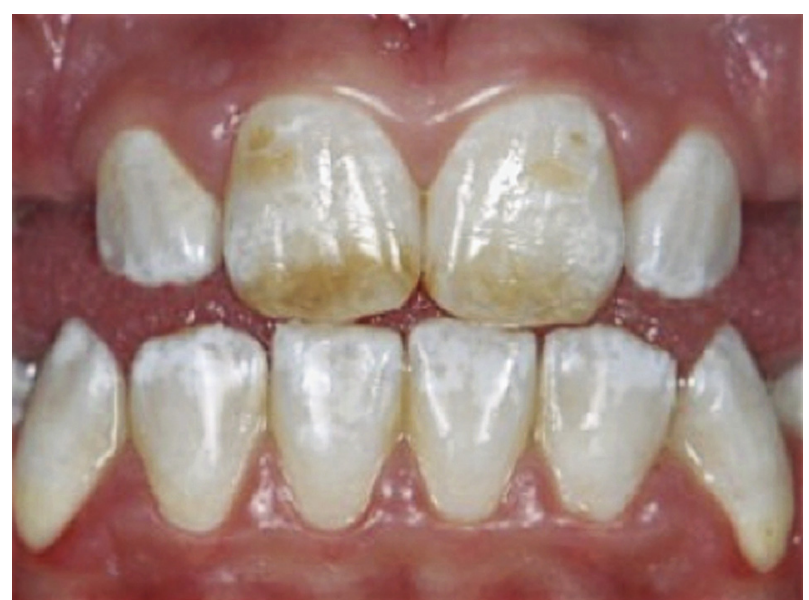

Fig. 9: TSIF stage 4 fluorosis. Fluorotic lesions involve the whole surface of the upper incisors. As well as the white parchment-like appearance, the central incisors present dark-brown areas due to post-eruptive infiltration of the hypomineralized enamel by exogenous chromophoric proteins.

Fig. 9 : Fluorose de stade 4 TSIF. L'atteinte fluorotique concerne l'ensemble de la surface des incisives maxillaires. Les incisives centrales présentent, en plus d'un aspect blanc parcheminé, des plages marron sombre consécutives à une infiltration postéruptive de l'émail hypominéralisée par les protéines chromophores exogènes.

organization of the hypomineralization resulting from dental fluorosis is the same as that encountered in early carious lesions. At a macroscopic level, the mineral structure appears unaffected. There is simply an increase in porosity along the interprismatic spaces and the striae of Retzius (as in early carious lesions), due to a reduction in the number of crystals but not of their size [17]. Free spaces in the enamel are l'émail (fig. 10) [16]. L'organisation de l'hypominéralisation consécutive à une fluorose dentaire est la même que celle rencontrée dans les lésions carieuses initiales. À l'échelle macroscopique, la trame minérale n'est pas perturbée. Il y a seulement une augmentation des porosités le long des espaces inter-prismatiques et des stries de Retzius (tout comme dans les lésions carieuses initiales) permise par une diminution du nombre des cristaux et non de leur taille [17]. 

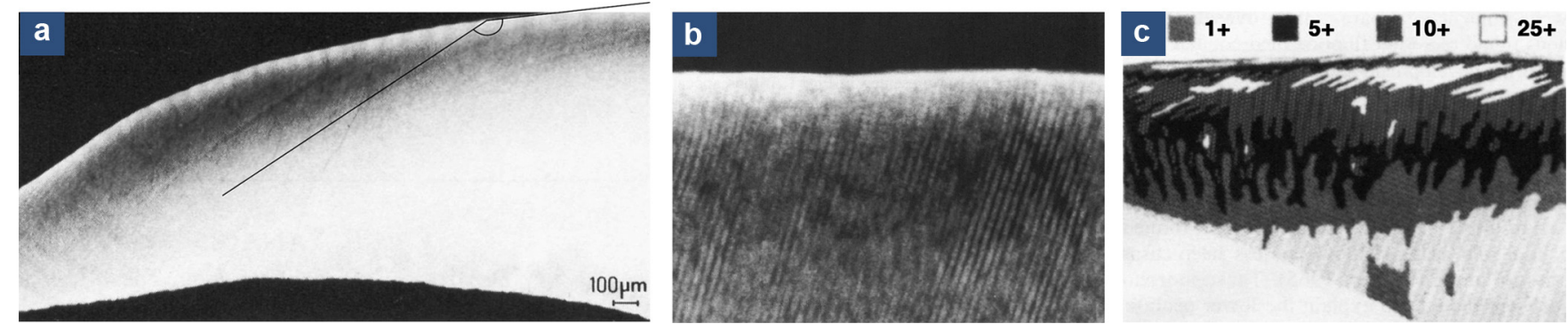

Fig. 10: Anatomopathological characteristics of fluorosis as seen on a transverse cross-section (the cervical localization of the fluorotic lesions without loss of substance shows that these are definitely fluoroses of TSIF stage 2/3): a: overall microradiograph (from Yanagisawa); b: microradiograph with greater degree of enlargement (from Fejerskov). The surface layer is perfectly mineralized. The demineralized zone extends below the surface at an obtuse angle and concerns only the external part of the enamel thickness. The prismatic structure of the enamel remains intact; $c$ : semi-quantitative mapping under polarized-light microscopy (from Fejerskov). The porosity of fluorotic enamel varies from 1 $+\%$ to $25+\%$. There is a descending gradient of porosity between the subsurface layer and the interior of the enamel $\left(1 / 4\right.$ at $25+\%, 1 / 4$ at $10+\%,{ }_{1}^{1} / 4$ at $5+\%$ and $1 / 4$ at $1+\%)$; i.e. the most hypomineralized enamel is in the subsurface layer, with a progressive return to a normal level of mineralization with increasing depth.

Fig. 10 : Les caractéristiques anatomopathologiques d'une fluorose à partir de section transversale (la localisation cervicale des lésions fluorotiques sans perte de substance indique que nous sommes surement face à des fluoroses TSIF 2/3) : a : microradiographie d'ensemble (d'après Yanagisawa); $b$ : microradiographie à plus fort grossissement (d'après Fejerskov). La couche de surface est parfaitement minéralisée. La zone de déminéralisation s'étend en subsurface selon un angle obtus et ne concerne que la partie externe de l'épaisseur amélaire. L'organisation prismatique de l'émail persiste ; c : cartographie semi-quantitative obtenue par microscopie à lumière polarisée (d'après Fejerskov). La porosité d'un émail fluorotique va de $1+\%$ à $25+\%$. Il existe un gradient décroissant du taux de porosité entre de la couche de subsurface et l'intérieur de l'émail ( $1 / 4$ de $25+\%, 1 / 4$ de $10+\%, 1 / 4$ de $5+\%$ et $1 / 4$ de $1+\%$ ) ; c'est-à-dire que l'émail le plus hypominéralisé se trouve en subsurface, puis retourne en profondeur progressivement à un taux de minéralisation normal.

occupied by ionic fluids and proteins, the origin of which (from the matrix or exogenous) has not yet been determined [18].

\section{Treatment}

The occurrence of fluorosis causing white defects could be considered an acceptable compromise in view of the priority given to the prevention of dental caries. However, this alteration of the enamel often has a psychological impact, sometimes even leading children to drop out of school $[19,20]$. The situation is aggravated by the fact that the disease preferentially affects the upper incisors, visible during a smile. The dentist must therefore offer an appropriate solution to these problems.

One possibility that is available to reduce the parchment-like appearance of fluorosed teeth is in-office bleaching using $10 \%$ carbamide peroxide. The aim of the whitening is to camouflage white spot defects by increasing the overall brightness of the teeth.

However, this is not always sufficient. In view of the histopathological similarity between fluorosis and early carious lesions, it seems possible, for well-defined cloudy areas, to add "erosion-infiltration" after whitening treatment. The urea contained in the carbamide peroxide deproteinizes the fluorotic enamel, thus ensuring good infiltration. A combination of these two treatments in such patients has so far given
Les espaces libres amélaires sont occupés par des fluides ioniques et des protéines dont l'origine (matricielles ou exogènes) n'est à ce jour pas déterminée [18].

\section{Traitement}

L'apparition de fluorose responsable de taches blanches pourrait être considérée comme un compromis acceptable par rapport à la priorité accordée à la prévention de la carie dentaire. Seulement, cette altération de l'émail est souvent mal vécue, conduisant parfois même à des déscolarisations $[19,20]$. Cette pathologie est d'autant mal tolérée qu'une de ses localisations préférentielles concerne les incisives supérieures, dents du sourire. Le praticien doit alors trouver des réponses acceptables face à ces demandes.

Une des alternatives possibles pour atténuer l'aspect parcheminé de la fluorose dentaire est de réaliser un éclaircissement ambulatoire au peroxyde de carbamide à $10 \%$. L'éclaircissement aura pour objectif de camoufler les défauts blancs en augmentant la luminosité générale des dents.

Seulement, cette proposition n'est pas toujours suffisante. Se reportant à la similitude histopathologie des fluoroses avec les lésions carieuses initiales, il apparaît possible, en cas de plage nuageuse bien délimitée, de compléter l'éclaircissement par un temps d'« érosion-infiltration ". L'urée contenue dans le peroxyde de carbamide assure la déprotéinisation de l'émail fluorotique, préalable à une bonne infiltration. L'association de 
White defects on enamel: Diagnosis and anatomopathology: Two essential factors for proper treatment (part 1)

Taches blanches de l'émail : diagnostic et anatomopathologie : deux données indispensables pour bien les traiter (partie 1)

perfectly satisfactory esthetic results with a clinical follow-up of 19 months [21].

\section{Traumatic hypomineralization}

Traumatic hypomineralization of a permanent tooth is a consequence of periodontal trauma affecting the deciduous teeth. This may involve displacements of all kinds (concussion, subluxation, luxation with or without lateral displacement, intrusion, extrusion, shedding/extraction), which represent $80 \%$ of trauma to the primary dentition [22]. Whatever the severity of this trauma, the appearance of sequellae is sporadic. A simple shock that often passes unnoticed during childhood may be the cause of the occurrence of these defects. Intrusion nevertheless remains the most harmful injury [23]. During the emergency consultation, the dentist can only offer parents a presumptive indication of the future risks.

Trauma confined to hard tissues and the pulp of deciduous teeth cannot in itself give rise to sequellae affecting the permanent tooth buds. However, resulting periapical infections can do so.

The close anatomical proximity that exists between the apexes of the anterior deciduous teeth and the germs of their permanent successors, that also display delayed calcification, explains this relationship. On the level of the incisors, the two types of dentition are separated only by a slender bony barrier less than $3 \mathrm{~mm}$ thick, or sometimes even by simple fibrous connective tissue. Slight periapical inflammation can then disturb mineralization of the underlying germ, depending on its degree of calcification. Generally speaking, it is disruption at the stage of maturation of the ameloblasts that leads to the appearance of traumatic hypomineralization. In the event of earlier disturbance, there may also be associated hypoplasia.

Other more serious sequellae classified by Andreasen (structural abnormalities [coronal and/or radicular] and positional abnormalities) are not mentioned here.

\section{Prevalence}

The prevalence of this hypomineralization is estimated as $5.2 \%$. This figure is not surprising, given that one third of children suffer a traumatic episode involving their deciduous teeth before the age of 5 . The early years of life are a period when children are learning to walk and exploring their environment. This frequently leads to premaxillary injuries. Recurrence of trauma has no impact on the occurrence of sequellae. However, age can affect both their nature and their severity.

\section{Diagnosis}

Traumatic hypomineralization can present a wide variety of clinical expressions differing in shape, outline, localization ces deux thérapeutiques chez ces patients présente à ce jour des résultats esthétiques entièrement satisfaisants avec un recul clinique de 19 mois [21].

\section{Hypominéralisation traumatique}

L'« hypominéralisation traumatique » de dent permanente est une séquelle consécutive à un traumatisme du parodonte des dents lactéales. II peut s'agir de toutes les formes de luxation (concussion, subluxation, luxation sans/avec déplacement latéral, intrusion, extrusion, expulsion/extraction), représentant $80 \%$ des traumatismes lactéales [22]. L'apparition de séquelles est sporadique quelle que soit la gravité du traumatisme. Une simple concussion, bien souvent passée inaperçue pendant la petite enfance, peut ainsi être mise en cause dans l'apparition de ces défauts. L'intrusion reste tout de même la plus délétère [23]. Le praticien, lors de la consultation d'urgence, ne peut délivrer aux parents que des présomptions de survenue.

Les traumatismes circonscrits aux tissus durs et à la pulpe des dents lactéales ne peuvent à eux seuls entraîner de séquelles sur les germes ascensionnels. En revanche, les infections du périapex qui en sont consécutives le peuvent.

La forte proximité anatomique existante entre les apex des dents lactéales antérieures et les germes des dents permanentes successionnelles arborant, en plus, une calcification tardive, explique cette interrelation. Dans le cas des incisives, seule une fine barrière osseuse de moins de $3 \mathrm{~mm}$ d'épaisseur, et parfois même un simple tissu conjonctif fibreux, sépare les deux dentures. Une sommaire inflammation du périapex peut alors perturber la minéralisation du germe sus-jacent selon son stade de calcification. De façon générale, c'est la perturbation du stade de maturation des améloblastes qui aboutit à l'apparition d'hypominéralisation traumatique. Lors de perturbation plus précoce, une hypoplasie peut également y être associée.

D'autres formes de séquelles plus grave (anomalies structurales [coronaires et/ou radiculaires] et anomalies de positions) classées par Andreasen ne sont pas évoquées ici.

\section{Prévalence}

La prévalence de cette hypominéralisation est évaluée à $5,2 \%$. Ce chiffre n'est pas étonnant, étant donné qu'un tiers des enfants est exposé avant l'âge de cinq ans à un épisode traumatiques des dents temporaires. Les premières années de la vie sont pour l'enfant une période d'apprentissage de la marche et de découverte de son environnement. Les blessures du prémaxillaire y sont fréquemment associées. La récurrence des traumatismes n'a pas d'effet sur la survenue des séquelles. En revanche, l'âge en a un sur leur nature et leur gravité.

\section{Diagnostic}

Les hypominéralisations traumatiques peuvent revêtir une grande variété d'expressions cliniques de part leur forme, leur contour, leur localisation et même leur teinte. Ce sont 


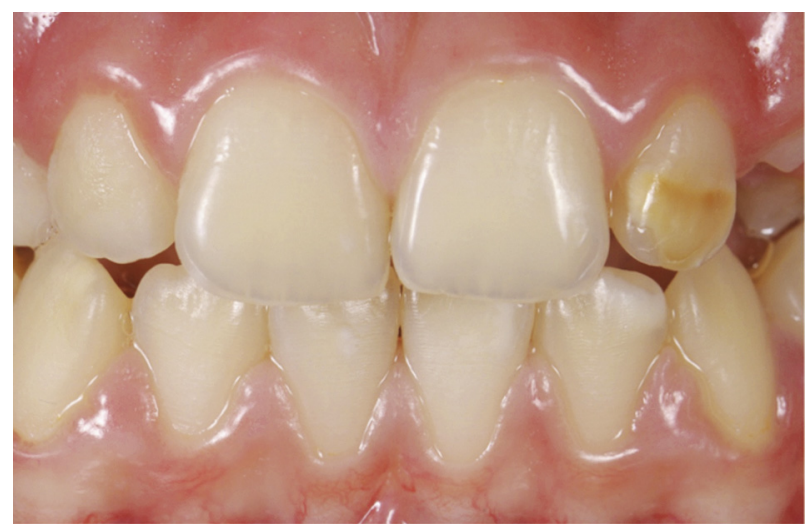

Fig. 11: Specific localizations in traumatic hypomineralization. Tooth 22 displays brown enamel discoloration without hypolasia. Tooth 32 is also affected by white discoloration. The mirror-image symmetry of these isolated enamel lesions is a pathognomonic sign of traumatic hypomineralization.

Fig. 11 : Spécificité de localisation des hypominéralisations traumatiques. La 22 présente une discoloration amélaire brune sans hypoplasie. La 32 est également atteinte d'une discoloration blanche. La localisation en miroir de ces atteintes amélaires isolées est un signe pathognomonique de l'hypominéralisation traumatique.

and even color. They are generally punctiform lesions situated on the incisal third of tooth crowns (fig. 2c).

They are often limited to one tooth, and asymmetrical with respect to the corresponding controlateral teeth. However, associated lesions can often be found on mandibular opponents (fig. 11).

Finally, it is the elective nature of traumatic hypomineralizations rather than their clinical presentation that provides the most useful diagnostic information (fig. 12). Medical history is not one of the leading criteria on account of its uncertain utility (it is sometimes difficult to remember a shock that occurred several years previously). The diagnosis of traumatic hypomineralization remains essentially diagnosis by exclusion.

\section{Anatomopathology}

The histopathology of traumatic hypomineralization is similar to that of WS and fluorosis. It too involves subsurface hypomineralization under a relatively well-mineralized surface layer (fig. 13a) [24]. The surface layer is once again the result of post-eruptive ionic reprecipitation.

On a microscopic scale, hypomineralization takes the form of an enlargement of the interprismatic sheath creating the impression of a gap (fig. 13b) (interprismatic gap not present in healthy enamel). It is these repeated gaps that deviate the trajectory of the light rays and, as was explained in the first section, are responsible for the white appearance of the lesion. généralement des lésions ponctiformes situées sur le tiers incisal des couronnes (fig. 2c).

Leur atteinte est bien souvent circonscrite à une dent et asymétrique par rapport aux dents homologues controlatérales. En revanche, des lésions associées peuvent être retrouvées sur les dents antagonistes mandibulaires (fig. 11). C'est finalement la nature élective des hypominéralisations traumatiques, plus que leur simple aspect clinique, qui renseigne le plus sur leur diagnostic (fig. 12). L'inconstance de l'intérêt de l'anamnèse n'en fait pas un critère prédominant (il est parfois difficile de se souvenir d'une concussion d'il y a plusieurs années). Le diagnostic des hypominéralisations traumatiques reste principalement un diagnostic d'exclusion.

\section{Anatomopathologie}

L'histopathologie des hypominéralisations traumatiques se rapproche de celle des WS et des fluoroses. Elle présente aussi une hypominéralisation de subsurface sous une couche de surface relativement bien minéralisée (fig. 13a) [24]. La couche de surface est encore une fois le résultat de reprécipitation ionique post-éruptive.

À l'échelle microscopique, l'hypominéralisation se traduit par un élargissement de la gaine interprismatique créant l'apparition d'une faille (fig. 13b) (faille interprismatique non présente dans l'émail sain). Ce sont ces failles répétées qui perturbent la trajectoire du rayon lumineux et contribuent, en plus de ce qui a été établi au premier chapitre, à la perception blanche de la lésion. 
White defects on enamel: Diagnosis and anatomopathology: Two essential factors for proper treatment (part 1)

Taches blanches de l'émail : diagnostic et anatomopathologie : deux données indispensables pour bien les traiter (partie 1)

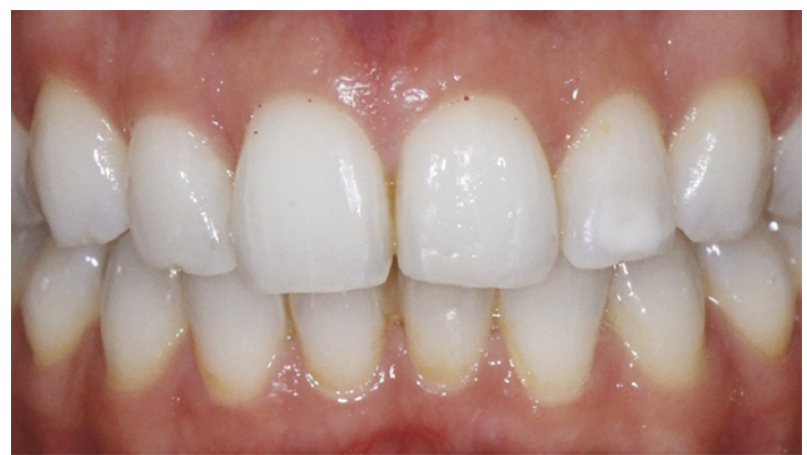

Fig. 12: Diagnosis of traumatic hypomineralization. The clinical appearance of the lesion (here very similar to that of fluorosis) provides very little etiological information. It is the location that is more useful diagnostically; isolated lesion with no controlateral symmetry.

Fig. 12 : Diagnostic d'une hypominéralisation traumatique. L'aspect clinique de la lésion (très semblable ici à une fluorose) informe peu sur son étiologie. C'est sa localisation élective qui informe le plus sur son diagnostic ; lésion isolée avec absence de symétrie sur la controlatérale.

However, their depth and morphology are just as variable as their expression; they depend on the circumstances of their occurrence. Thus, just like WS and fluoroses, they can sometimes extend like drops of oil below the surface of the enamel which they then encounter at an obtuse angle (fig. 13a). At other times, they may adopt a circular shape and form an acute angle with the enamel surface (fig. 13c) [25].

\section{Treatment}

It is due to these inconsistent angles that the results of treatment of traumatic hypomineralization by erosion-infiltration are difficult to predict.

On account of the acute angle, the infiltration is often incomplete on the margins, leading to a visual contouring of the lesion known as the "edge effect" (fig. 14). The erosion stage eliminates the thin, relatively well-mineralized surface layer, making only the central part of the "body" accessible to the resin, while on the edges of the lesion, in the acute angle, erosion alone cannot remove the peripheral lips of healthy enamel. These overhangs prevent the resin from penetrating the porous areas on the edges of the lesion. The center of the spot disappears but a more or less homogeneous white outline remains. The "patch" appearance produced by this "edge effect" is unfortunately sometimes more unsightly than the spot itself.

Conversely, in the presence of an obtuse angle (as in the case of WS and fluorosis), the erosion stage is effective. Complete infiltration is obtained over the whole of the hypomineralized area and the spot disappears totally.
En revanche, leur profondeur et leur morphologie sont toutes aussi variables que leur expression; elles dépendent des circonstances de survenue. Ainsi, parfois elle s'étend, tout comme les WS et les fluoroses, en goutte d'huile sous la surface amélaire y présentant alors un angle obtus (fig. 13a). Et d'autre fois, elle acquiert une morphologie circulaire formant des angles aigus par rapport à la surface amélaire (fig. 13c) [25].

\section{Traitement}

Ce sont ces inconstances d'angulation qui rendent aujourd'hui le traitement par « érosion-infiltration » des hypominéralisations traumatiques peu prédictif.

En effet, à cause de cette angulation aiguë, l'infiltration est souvent incomplète au niveau des marges produisant visuellement un détourage de la lésion appelé « effet de bord » (fig. 14). L'étape d'érosion élimine la mince couche de surface relativement minéralisée de la lésion rendant accessible à la résine seulement la partie centrale de son «corps». Tandis qu'au pourtour de la lésion à angle aigu, l'érosion ne peut à elle seule éliminer les béquets périphériques d'émail sain existants ; l'accès aux porosités n'étant en regard de ces béquets pas libéré, la résine ne peut y pénétrer. II se produit alors une disparition de la tache en son centre associée à la préservation d'un fin contour blanc plus ou moins homogène. L'effet pastille provoqué par cet « effet de bord » est malheureusement parfois encore plus disgracieux que la tache en ellemême.

Inversement, lors d'une angulation obtus (comme dans les cas de WS et fluorose), l'étape d'érosion est suffisante. L'infiltration est complète sur l'ensemble de I'hypominéralisation ; la tache disparaît alors complètement. 

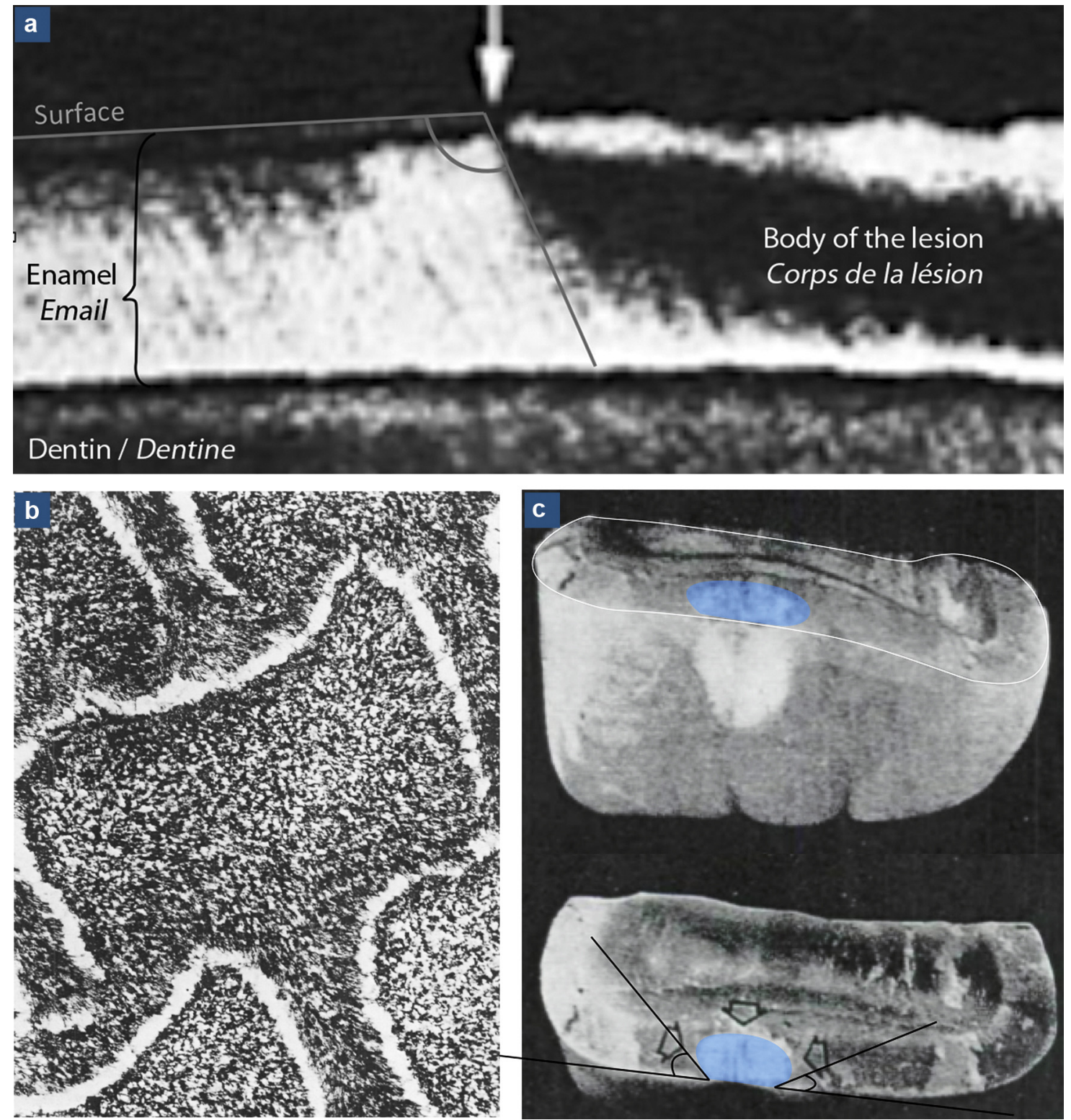

Fig. 13: Anatomopathological characteristics of traumatic hypomineralization as seen on a transverse cross-section: a: study of birefringence of a specimen under water by polarized-light microscopy (from Thylstrup). With this method, zones with more than 5\% hypomineralization appear dark. A thin layer of relatively well-mineralized enamel remains between the tooth surface and the lesion. Here, the lesion forms an obtuse angle with the surface of the enamel; b: transverse cross-section of an enamel prism (head of prism $\approx 3 \mu$ ) observed by scanning electron microscopy (from Andreasen). The prismatic structure is conserved. However, a gap of approximately $100 \mathrm{~nm}$ can be observed at the level of the prism sheath; $\mathbf{c}$ : photograph of traumatic hypomineralization of a fractured central incisor (from Andreasen). The lesion (blue) is circular in shape, in the thickness of the enamel. Here, it forms an acute angle with the surface.

Fig. 13 : Les caractéristiques anatomopathologiques d'un hypominéralisation traumatique à partir de section transversale : a : étude de la biréfringence de l'échantillon sous eau par microscopie à lumière polarisée (d'après Thylstrup). La méthode fait apparaître en sombre les zones hypominéralisées de plus de $5 \%$. Entre la surface de la dent et la lésion persiste une fine couche d'émail relativement bien minéralisé. L'angulation de la lésion obtenue par rapport à la surface amélaire forme ici un angle obtus ; b : coupe transversale d'un prisme amélaire (tête du prisme $\approx 3 \mu$ ) observé au microscope électronique à balayage (d'après Andreasen). L'organisation prismatique est conservée. En revanche, il y a apparition d'une faille d'environ $100 \mathrm{~nm}$ au niveau de la gaine du prisme ; c : photographie d'une hypominéralisation traumatique d'une incisive centrale fracturée (d'après Andreasen). La lésion (bleue) prend une forme circulaire dans l'épaisseur de l'émail. Son angulation par rapport à la surface est ici aigu. 
White defects on enamel: Diagnosis and anatomopathology: Two essential factors for proper treatment (part 1) Taches blanches de l'émail : diagnostic et anatomopathologie : deux données indispensables pour bien les traiter (partie 1)
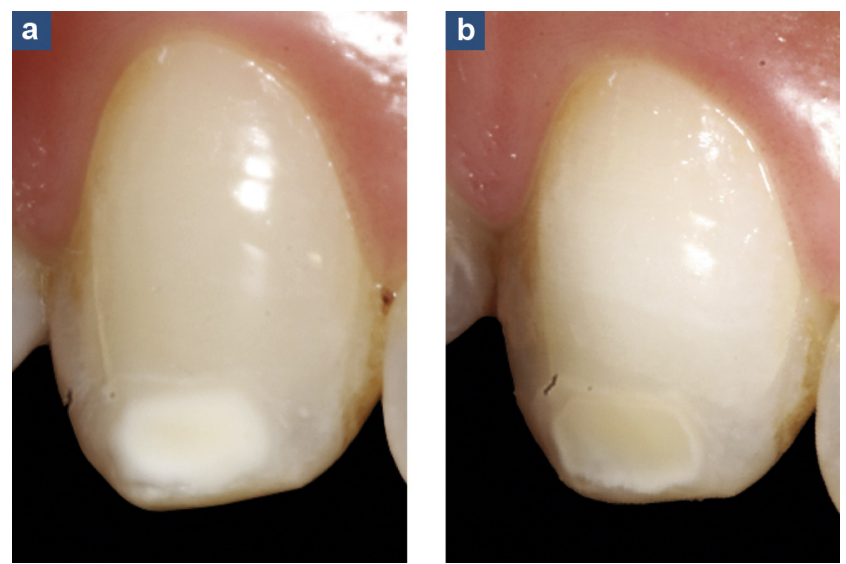

Fig. 14: Risk of appearance of an "edge effect" after erosion-infiltration of traumatic hypomineralization: a: the clinical appearance of a white lesion due to traumatic hypomineralization does not reveal its underlying morphology; b: unsatisfactory clinical result after erosion-infiltration using the supplier's protocol. The persistence of a peripheral white halo, or "edge effect", is the result of incomplete infiltration. It appears when the lesion is circular, forming an acute angle with the tooth surface.

Fig. 14 : Risque d'apparition d'« effet de bord » après érosion-infiltration d'une hypominéralisation traumatique : a : l'aspect clinique de la lésion blanche d'une hypominéralisation traumatique ne laisse pas percevoir sa morphologie sous-jacente ; $b$ : résultat clinique insatisfaisant après érosion-infiltration selon le protocole du fabriquant. La persistance d'un halot périphérique blanc, appelé « effet de bord », est la conséquence d'une l'infiltration incomplète. Elle apparaît lorsque la lésion est circulaire, à angle aigu par rapport à la surface de la dent.

These inconsistent results mean that treatment of traumatic hypomineralization by "erosion-infiltration" should be undertaken with due caution. Finally, it is the dentist's clinical experience in this field that will lead him/her to suspect the presence of one type of morphology rather than another. Modifications of the protocol are currently being envisaged to improve the effectiveness of erosion-infiltration treatment in all situations of traumatic hypomineralization. Increased peripheral erosion, with or without light sandblasting, should enable this difficulty to be overcome.

\section{MIH: molar-incisor hypomineralization}

Among the different clinical presentations of white defects, $\mathrm{MIH}$ is the least well-known.

\section{Prevalence}

According to the results of surveys [26,27] of members of associations of pediatric dentists, the prevalence of MIH today lies somewhere between $3 \%$ and $25 \%$. Prevalence seems to vary depending on the country, region or age-group considered. It is still difficult to judge whether it is increasing.

\section{Diagnosis}

The clinical expression of the disease implies the presence of qualitative enamel defects in at least one of the four first permanent molars (FPM), associated or not with lesions of
Cette inconstance de résultat fait que le traitement par " érosion-infiltration » des hypominéralisations traumatiques doit être entrepris avec prudence. C'est finalement l'expérience clinique du praticien dans ce domaine qui lui permet d'augurer d'une morphologie en présence plutôt qu'une autre. Des adaptions du protocole sont actuellement envisagées pour améliorer l'efficacité du traitement d'érosion-infiltration dans toutes les situations d'hypominéralisation traumatique. Une érosion plus importante de la périphérie, associée ou non à un léger sablage, devrait permettre de régler cette difficulté.

\section{MIH : hypominéralisation molaire-incisive}

La MIH de l'anglais « Molar Incisor Hypomineralisation » est la pathologie la moins connue du tableau clinique des taches blanches.

\section{Prévalence}

D'après les résultats d'enquêtes [26,27] réalisées auprès de praticiens appartenant aux sociétés de dentisterie pédiatrique, la prévalence des $\mathrm{MIH}$ serait aujourd'hui comprise entre $3 \%$ et $25 \%$. La prévalence semble varier en fonction des pays, des régions ou des classes d'âge prises en compte. Il est encore difficile d'estimer son évolution.

\section{Diagnostic}

L'expression clinique de la maladie implique la présence de défauts qualitatifs de l'émail sur au moins une des quatre premières molaires permanentes (PMP) pouvant être 


\section{Table IV}

Chawla MIH classification. When MIH is diagnosed, the Chawla classification, correlated with the Farah mineral density data, uses visual observation of the shade of opacity to determine the degree of mineralization (and thus hypomineralization) of the defect. An MIH defect perceived as white on a PMP/IP indicates that it presents a mineral density of $2.22 \mathrm{~g} / \mathrm{m}^{3}$. This then allows the calculation of the degree of hypomineralization relative to the healthy enamel (mineral density of $2.75 \mathrm{~g} / \mathrm{m}^{3}$ ). This article deals only with MIH white spots, which present slight hypomineralization. If the defect exhibits discoloring, whitening becomes necessary in order to return to a white spot situation.

\section{Tableau IV}

Classification des MIH de Chawla. Lors d'un diagnostic de $\mathrm{MIH}$, la classification de Chawla corrélée aux données sur la densité minérale de Farah permet, par simple relevé visuel de la teinte de l'opacité, de déterminer le degré de minéralisation (donc d'hypominéralisation) du défaut. Un défaut de MIH perçu blanc sur une PMP/IP indique qu'il présente une densité minérale de $2,22 \mathrm{~g} / \mathrm{m}^{3}$. Il est alors possible de quantifier le degré d'hypominéralisation par rapport à l'émail sain (densité minérale à $2,75 \mathrm{~g} / \mathrm{m}^{3}$ ). Seuls les défauts blancs de $\mathrm{MIH}$, présentant une hypominéralisation légère, sont concernés par cet article. Si le défaut est coloré, une étape d'éclaircissement est indispensable afin de se remettre dans le cas d'une tache blanche.

\begin{tabular}{lll}
\hline $\begin{array}{l}\text { Severity according } \\
\text { to Chawla/Sévérité } \\
\text { selon Chawla }\end{array}$ & $\begin{array}{l}\text { Clinical criteria (shade)/ } \\
\text { Critères cliniques (teinte) }\end{array}$ & $\begin{array}{l}\text { Mineral density (according to Farah). Degree of } \\
\text { mineralization indicator/Densité minérale } \\
\text { (d'après Farah). Indicateur du degré } \\
\text { de minéralisation }\end{array}$ \\
\hline Slight MIH/MIH légère & $\begin{array}{l}\text { Creamy-white opacity of enamel/ } \\
\text { Opacités blanc-crème de l'émail }\end{array}$ & $2.22 \mathrm{~g} / \mathrm{m}^{3}$ \\
\hline Severe MIH/MIH sévère & $\begin{array}{l}\text { Browny-yellow opacity of enamel/ } \\
\text { Opacités jaunes brun de l'émail }\end{array}$ & Less than $1.95 \mathrm{~g} / \mathrm{m}^{3} / / \mathrm{nférieure} \mathrm{à} \mathrm{1,95} \mathrm{g} / \mathrm{m}^{3}$ \\
\hline
\end{tabular}

the permanent incisors (PI). Sometimes, the cusps of the canines and the second molars are also involved.

In this context, the dentist should pay particular attention to one or several of the following diagnostic factors that may be encountered during a consultation:

- clearly-defined opacities, white, yellow or brown in color, limited to the occlusal half of one (of the) crown(s) of the FPM and/or PI (fig. 2d).

Due to the non-homogeneous nature of the involvement, these opacities may be irregular on a single tooth, and may be present asymmetrically on homologous teeth;

- splinters of enamel (post-eruptive, due to chemical and mechanical stresses) modifying the occlusal anatomy of the FPM. The thickness of the non-fractured enamel is normal;

- children who are particularly fearful of dental treatment because of excessive tooth sensitivity, and difficulties of anesthesia due to underlying pulpar inflammation [28]. Brushing their teeth is also a painful experience for these children so their oral hygiene is defective, encouraging the simultaneous development of dental caries and making a positive diagnosis still more difficult;

- atypical shapes/edges of restorations and/or early failures of restorations; PI restorations with no antecedent of trauma; associée ou non à une atteinte des incisives permanentes (IP). Parfois les cuspides des canines et des secondes molaires sont également concernées par l'atteinte.

Dans ce contexte pathologique, le praticien doit porter une vigilance toute particulière lorsqu'il observe au décours d'une consultation, un ou plusieurs éléments d'aide au diagnostic suivant :

- des opacités bien délimitées de couleur blanche, jaune ou marron, circonscrites à la moitié occlusale d'une (des) couronne(s) des PMP et/ou IP (fig. 2d).

De par le caractère inhomogène de l'atteinte, ces opacités peuvent être inégales sur une même dent, et leur présence peut être asymétrique sur les dents homologues ;

- des éclats amélaires (post-éruptifs sous l'effet des contraintes chimiques et mécaniques) perturbant l'anatomie occlusale des PMP. L'émail non fracturé présentant une épaisseur normale ;

- une forte anxiété face aux soins provoquée par des sensibilités dentaires accrues et des difficultés d'anesthésie dues à une inflammation pulpaire sous-jacente [28]. Le brossage est également perçu par l'enfant comme une épreuve douloureuse. Son hygiène est défectueuse favorisant l'instauration concomitante d'un processus carieux rendant encore plus difficile le diagnostic positif ;

- des formes/marges de restaurations atypiques et/ou des échecs précoces de restaurations ; des restaurations sur les IP sans antécédent de traumatisme ; 
White defects on enamel: Diagnosis and anatomopathology: Two essential factors for proper treatment (part 1)

Taches blanches de l'émail : diagnostic et anatomopathologie : deux données indispensables pour bien les traiter (partie 1)

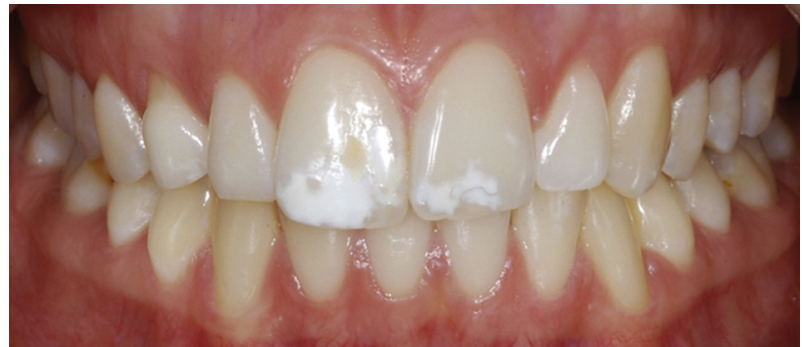

Fig. 15: Diagnosis of enamel involvement in MIH. Its localization in the incisal half and the irregular, asymmetrical appearance of this clearly-outlined creamy-white opacity on the central incisors suggest that it is due to MIH. The severe lesion (brown stain) on tooth 46 confirms the diagnosis that the patient's dentition is affected by MIH.

Fig. 15 : Diagnostic d'une atteinte amélaire par MIH. La localisation dans la moitié incisale ainsi que l'aspect asymétrique et irrégulière aux contours nets de l'opacité blanc-crème des incisives centrales font penser à une atteinte par $\mathrm{MIH}$. L'atteinte sévère (brune) de la 46 vient confirmer le diagnostic d'atteinte par $\mathrm{MIH}$ de la denture du patient.

— unexplained extractions of PFM in a mouth free of dental caries.

N.B.: when MIH is suspected in the presence of anterior WS, the diagnosis should be systematically confirmed by examination of defects on at least one PFM. Involvement of the incisors remains secondary to that of the molars.

It is often the severity of the disease [simplified Chawla Severity Index [29] (Table IV)] on the molars that leads to involvement of the incisors. When there is "severe" MIH of the PFM, $70 \%$ of the PI also show signs of the disease [30].

The disease is always more severe on the PFM than on the PI (respectively $37.9 \%$ "severe" defects versus $4.9 \%$ ). Consequently, the defects on the incisors are mostly "mild" $(95.1 \%)$

Farah's study [31] relates the severity of the disease to mineral density (Table IV). The mineral density of the enamel substrate provides information not only on the degree of hypomineralization but also concerning its intrinsic mechanical properties. This explains why teeth with "severe" MIH and seriously diminished mineral density suffer from fragility and early decay misleadingly suggestive of hypoplasia. It should be noted that because of the absence of occlusal loads bearing directly on the lesions incisors are better protected than FPM against post-eruptive degradation.

Finally, depending on the conditions of occurrence (degrees of severity) and the localization of MIH, incisors with the disease mainly present "mild" white defects and a depth of enamel that remains intact over the years (fig. 15).
— des extractions inexpliquées de PMP dans une bouche indemne de caries.

Attention, lors d'une présomption de $\mathrm{MIH}$ en présence de taches blanches antérieures, le diagnostic doit être systématiquement confirmé par l'examen de défauts sur au moins une PMP. En effet, l'implication des incisives reste « secondaire » à celle des molaires.

C'est la sévérité de l'atteinte (classification simplifiée de Chawla [29]) (Tableau IV) des molaires qui induit bien souvent une atteinte des incisives. Lorsque les PMP exhibent une MIH « sévère », $70 \%$ des IP montrent alors également des signes d'atteintes par la pathologie [30].

La gravité de la pathologie reste bien plus importante sur les PMP que sur les IP (respectivement 37,9\% de défauts « sévères » contre 4,9\%). De ce fait, les incisives présentent principalement des défauts « légers » $(95,1 \%)$.

L'étude de Farah [31] met en relation la sévérité de la pathologie avec son niveau de densité minérale (Tableau IV). En plus du degré d'hypominéralisation, la valeur de densité minérale du substrat amélaire informe sur ses capacités mécaniques intrinsèques. C'est ce qui explique que des dents porteuses de «MIH sévère » de densité minérale fortement affaiblie présentent une fragilité et un délabrement précoce faisant faussement penser à une hypoplasie. Il est à noter que contrairement au PMP, l'absence de charges occlusales établies directement sur les lésions des incisives les préserve relativement bien des dégradations post-éruptives.

Finalement, selon les conditions d'apparition (degrés de sévérité) et de localisation des $\mathrm{MIH}$, les incisives porteuses de la pathologie présentent principalement des défauts blancs " légers » où l'épaisseur de l'émail reste intacte au fil des ans (fig. 15). 

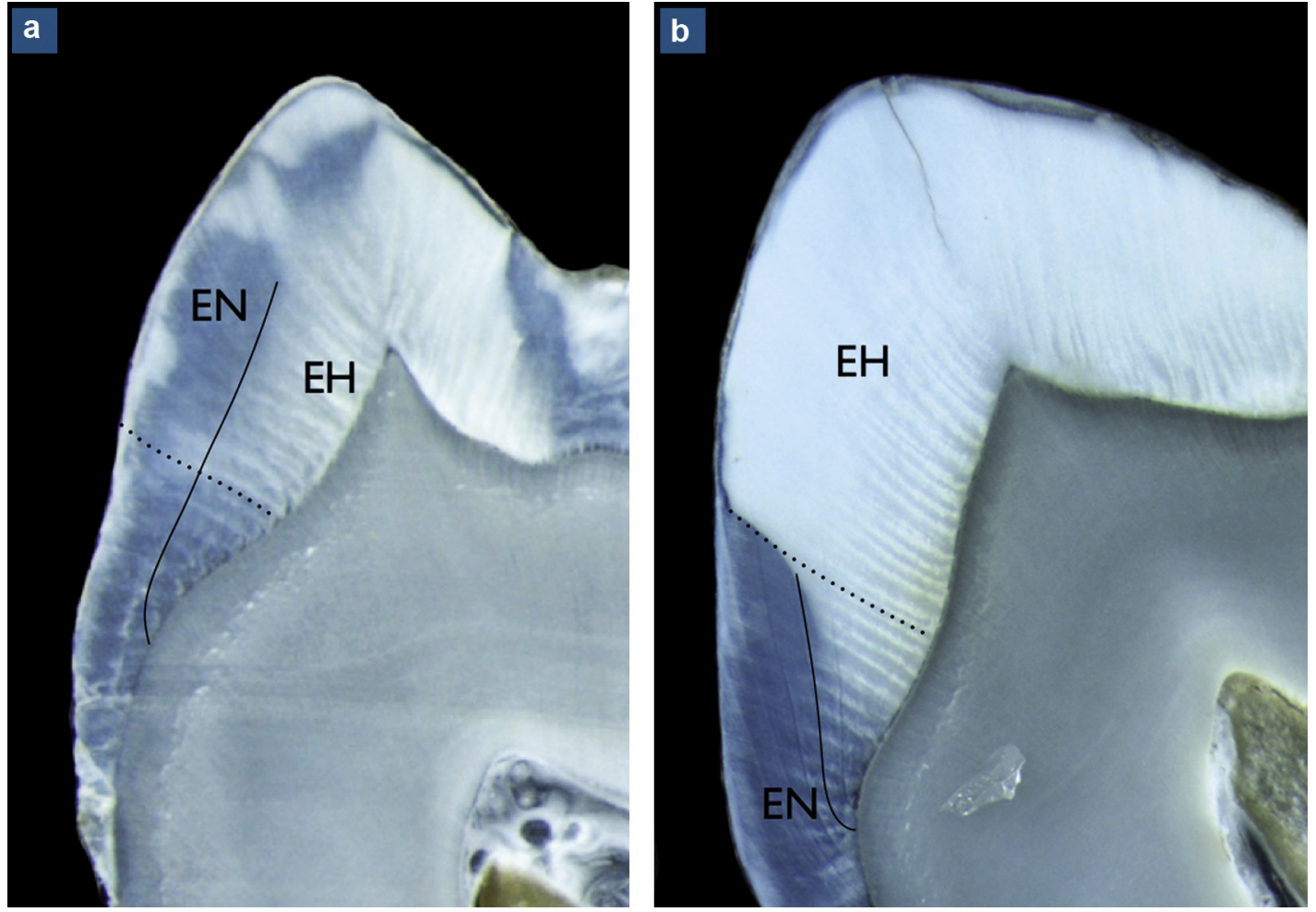

Fig. 16: Anatomopathological characteristics of "mild" (a) and "severe" (b) MIH as seen on transverse crosssections observed by optical microscopy under incident light (courtesy of Norén JG): a: in the case of "mild" MIH, the hypomineralized enamel (EH) (greater than 5\%) is located in the inner third, along the dentino-enamel junction. Hypomineralization tends to follow the Hunter-Schreger bands (dotted line), and stops at one of the striae of Retzius (continuous line). A layer of normal enamel (EN) covers the hypomineralized enamel (EH). The less severe the MIH, the deeper the localization of the hypomineralized enamel; $\mathbf{b}$ : in the case of severe MIH, the whole depth of the enamel is affected by hypomineralization of more than $5 \%$. The hypomineralization stops at the level of one of the HunterSchreger bands (dotted line). The cervical parts of the teeth affected by MIH possess normal enamel (EN).

Fig. 16 : Les caractéristiques anatomopathologiques d'une $\mathrm{MIH}$ « legère » (a) et « sévère » (b) à partir de sections transversales observées sous microscopie optique à lumière incidente (courtoisie du Norén JG) : a : dans le cas de " MIH légère ", l'émail hypominéralisé (EH) (supérieur à $5 \%$ ) se situe dans le tiers interne, le long de la jonction amélodentinaire. L'hypominéralisation tend à suivre les bandes de Hunter-Schreger (trait pointillé) et s'arrête le long d'une strie de Retzius (trait plein). Une couche d'émail normal (EN) recouvre l'émail hypominéralisé (EH). Plus le degré de severité de la MIH est faible, plus l'émail hypominéralisé est localisé en profondeur ; b : dans le cas de « MIH sévère », c'est la totalité de l'épaisseur de l'émail qui est atteint par une hypominéralisation d'au moins supérieure à $5 \%$. L'hypominéralisation s'arrête le long d'une bande de Hunter-Schreger (trait pointillé). La partie cervicale des dents atteintes par MIH présente un émail normal (EN).

For a positive diagnosis, the dentist should back up clinical observation by seeking to identify one of the currentlyaccepted risk factors. Talking to the parents and examination of the medical file should reveal at least one of the following (even though the etiology appears to be multifactorial [32] and remains controversial):

- respiratory disease responsible for hypoxia (premature birth, asthma, pneumopathies, chronic bronchitis, etc.);

— repeated infectious episodes accompanied by fever (otitis, pharyngitis, measles, mumps, etc.);
Le diagnostic positif s'applique, en complément de l'observation clinique, à rechercher un des facteurs de risques actuellement identifiés. Le questionnement des parents et la lecture du carnet de santé doivent évoquer au moins un des éléments suivants (même si l'étiologie semble multifactorielle [32] et toujours controversée):

- une pathologie respiratoire responsable d'hypoxie (naissance prématurée, asthmes, pneumopathies, bronchites chroniques. ..) ;

- des épisodes infectieux répétés accompagnés de fièvre (otites, angines, rougeoles, oreillons...) ; 
White defects on enamel: Diagnosis and anatomopathology: Two essential factors for proper treatment (part 1)

Taches blanches de l'émail : diagnostic et anatomopathologie : deux données indispensables pour bien les traiter (partie 1)
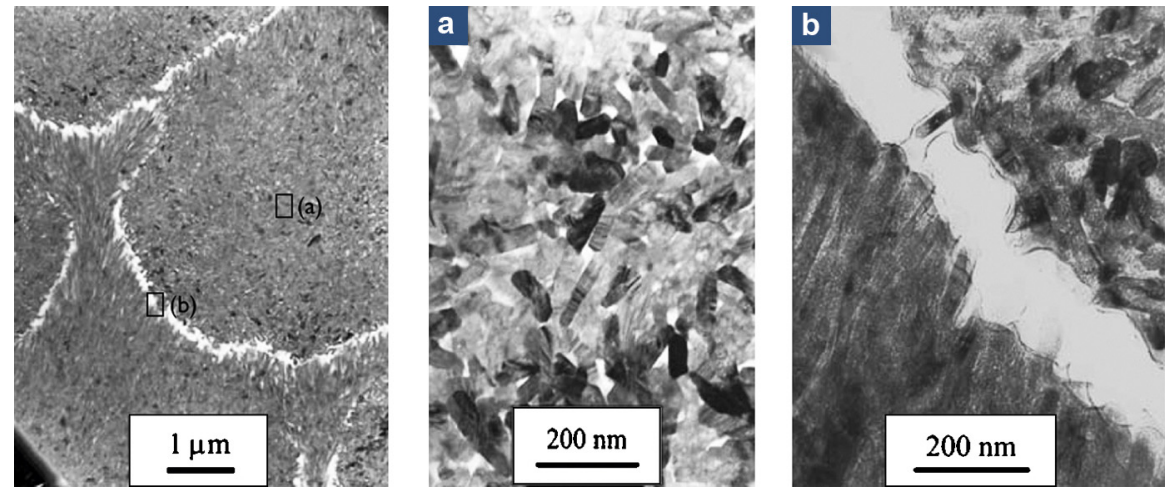

Fig. 17: Anatomopathological characteristics of MIH as seen on transverse cross-sections of enamel prisms observed by scanning electronic microscopy (from Xie). The prismatic structure is conserved. However, a gap of approximately $150 \mathrm{~nm}$ can be observed at the level of the prism sheath.

Fig. 17 : Les caractéristiques anatomopathologiques d'une MIH à partir de coupes transversales de prismes amélaires observées sous microscopie électronique à balayage (d'après Xie). L'organisation prismatique est conservée. En revanche, il y a apparition d'une faille d'environ $150 \mathrm{~nm}$ au niveau de la gaine du prisme.

— excessive exposure to dioxine (mother's milk, environmental situation, etc.)

\section{Anatomopathology}

Analysis of the histopathological data relating to MIH [33,34] reveals a topography of hypomineralization completely unlike that encountered in WS and fluorosis. Hypomineralization in MIH begins at the dentino-enamel junction and not at the surface of the enamel. This is why, in cases of "mild" MIH, hypomineralization remains limited to the inner third. The outer two third of enamel covering the internal hypomineralization remain relatively intact (fig. 16a). The junction between the hypomineralized internal enamel and the surface enamel is situated at the level of one of the striae of Retzius. In contrast, in cases of severe MIH, the whole of the enamel layer is hypomineralized (fig. 16b) and complex restoration treatment is required.

Microscopically, in hypomineralized enamel there is a separation between the interprismatic spaces creating large $(200 \mathrm{~nm})$ gaps [35] where a protein-rich matrix accumulates [36] (fig. 17). This microscopic organization is comparable with that noted in cases of traumatic hypomineralization (fig. $13 b)$.

\section{Treatment}

After the functional management of hypomineralization of the FPM, the dentist treating MIH is generally faced with the need to propose esthetic treatment of the anterior sector, which is often involved only to a mild degree. The internal localization of hypomineralization in "mild" MIH represents the only real
— une exposition accrue à la dioxine (lait maternelle, cartographie environnementale).

\section{Anatomopathologie}

L'analyse des données histopathologiques des $\mathrm{MIH}[33,34]$ montre une topographie de l'hypominéralisation complètement différente de celle rencontrée dans les WS et les fluoroses. L'hypominéralisation des MIH débute à la jonction amélo-dentinaire, et non à la surface de l'émail. C'est ce qui explique qu'en cas de «MIH légère » I'hypominéralisation reste circonscrite au tiers interne. Les deux tiers externes d'émail recouvrant l'hypominéralisation interne constitue un émail relativement intact (fig. 16a). La jonction entre l'émail interne hypominéralisé et l'émail de surface se fait au niveau d'une strie de Retzius. En revanche, lors d'une « $\mathrm{MIH}$ sévère », c'est l'ensemble de l'épaisseur amélaire qui est hypominéralisé (fig. 16b) nécessitant un recours à des thérapeutiques restauratrices complexes.

L'émail hypominéralisé présente microscopiquement une disjonction des espaces interprismatiques créant de larges failles $(200 \mathrm{~nm})$ [35] où s'accumule une matrice riche en protéines [36] (fig. 17). Cette organisation microscopique est à rapprocher de celle retrouvée dans les cas d'hypominéralisation traumatique (fig. 13b).

\section{Traitement}

En cas de $\mathrm{MIH}$, le praticien, après avoir considéré la prise en charge fonctionnelle des hypominéralisations des PMP, se trouve généralement confronté à devoir proposer une prise en charge esthétique du secteur antérieur bien souvent seulement atteint à un degré « léger ». Seulement la localisation 

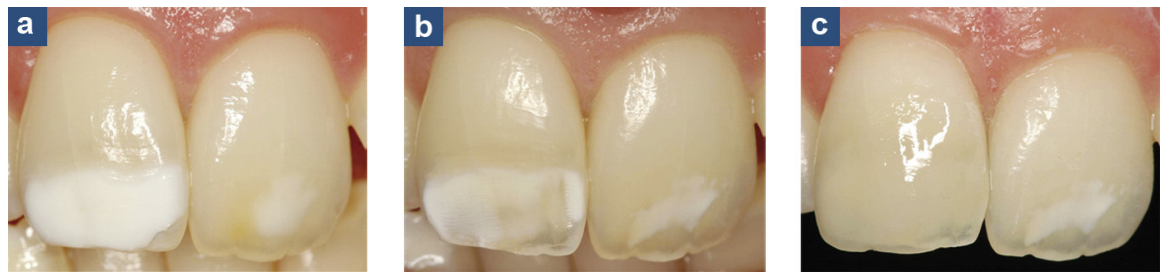

Fig. 18: Difficulty of therapeutic management of "mild" MIH: a: initial situation. The central incisors show signs of mild MIH. The extensive opacity visible on 11 is described as a handicap to the patient's social life; b: mega-abrasion undertaken to remove the opacity does not appear to be a success. The incisal margin has become very narrow and further abrasion would lead to its collapse. Since the "mild" MIH lesion is situated in the inner third of the thickness of the enamel, its elimination requires removal of large quantities of tissue. This treatment alone is inappropriate and cannot satisfy the patient's esthetic demand; $c$ : a stratified composite restoration was then undertaken. It was difficult to hide the persistent opaque substrate. This affects the final result. Fig. 18 : Difficulté de mise ouvre thérapeutique lors de «MIH légère » : a : situation initiale. Les incisives centrales présentent une atteinte par MIH légère. L'opacité fortement étendue de la 11 est décrite comme gênante pour la vie sociale de la patiente ; b : la méga-abrasion entreprise pour éliminer l'opacité ne laisse pas percevoir de succès. Le bord libre apparaît très fortement aminci. La poursuite de la méga-abrasion conduirait à l'effondrement du bord libre. En effet, la lésion d'une « MIH légère » étant située dans le tiers interne de l'épaisseur amélaire, l'élimination nécessite d'être conséquente. Cette thérapeutique seule est inadaptée et ne peut répondre à la demande esthétique de la patiente ; $\mathrm{c}$ : une restauration composite par stratification est alors entreprise. II est difficile de cacher le fond opaque persistant. Le résultat final en est altéré.

obstacle to the establishment of a treatment plan in conformity with the notion of tissue preservation.

Since a "mild" MIH lesion is located beneath the superficial two third of relatively healthy enamel, the erosion-filtration protocol does not seem appropriate, requiring excessively severe prior erosion. Similarly micro/mega-abrasion, regularly proposed for the elimination of white marks, is totally inappropriate in this case. It would inevitably lead to complete elimination of the enamel substrate.

The therapeutic alternative based on bonding protocols is effective but also encounters difficulties:

- either the whole of the opacity has to be removed, and the adhesion substrate is no longer enamel but dentin (with a $300,000 \mathrm{rpm}$ bur it is impossible to stop precisely at the DEJ). This change of substrate at the bonding interface is today still an unfavorable factor for ageing of the bonded restoration (early breakdown of the bond by MMPs in the dentin);

— or the opacity will be partially eliminated, without removal of all the enamel. However, adhesion to enamel damaged by MIH also appears difficult. Standard bonding procedures have to be adapted to include an initial stage of deproteinization (using hypochlorite, for example) and a difficult masking stage using stratified composite to hide the white mark (fig. 18).

It is clear that a new conservative approach to bio-mimetic treatment for white marks due to MIH in young patients has still to be invented. Meanwhile, since incisors with "mild" interne de l'hypominéralisation des $\mathrm{MIH}$ « légères » constitue une véritable problématique face à la volonté d'établir un traitement en accord avec la notion de préservation tissulaire. La lésion d'une MIH légère étant située profondément sous deux tiers d'émail superficiel relativement sain, le protocole d'«érosion-infiltration » n'apparaît pas être adéquat. L'érosion préalable devrait être trop conséquente. De même, la micro-/méga-abrasion régulièrement proposée pour faire disparaître les taches blanches n'a alors dans ce cas plus aucun sens. Elle conduirait immanquablement à l'élimination complète du substrat amélaire.

L'alternative thérapeutique des protocoles d'adhésion bien qu'efficace, reste également mise à mal :

— soit il s'agit d'éliminer la totalité de l'opacité et l'adhésion n'est plus amélaire mais dentinaire (il est impossible avec une fraise tournant à 300000 tours par minute de s'arrêter pile à la JAD). Ce changement de substrat à l'interface de collage reste aujourd'hui un élément moins favorable au vieillissement de la restauration adhésive (dégradation précoce du joint par les MMPs dentinaires) ;

— soit il s'agit d'éliminer partiellement l'opacité tout en restant dans l'émail. Seulement, le collage sur le substrat amélaire lésé par MIH apparaît également délicat. II requiert une adaptation des procédures standard de collage par l'inclusion d'une étape initiale de dé-protéinisation (par exemple à l'hypochlorite) et une étape de masquage délicate de la tache blanche à l'aide d'une stratification de composite (fig. 18).

II apparaît évident qu'une nouvelle approche conservatrice de soins biomimétiques doit encore être inventée dans les cas des taches blanches de $\mathrm{MIH}$ des jeunes patients. En 
White defects on enamel: Diagnosis and anatomopathology: Two essential factors for proper treatment (part 1)

Taches blanches de l'émail : diagnostic et anatomopathologie : deux données indispensables pour bien les traiter (partie 1)
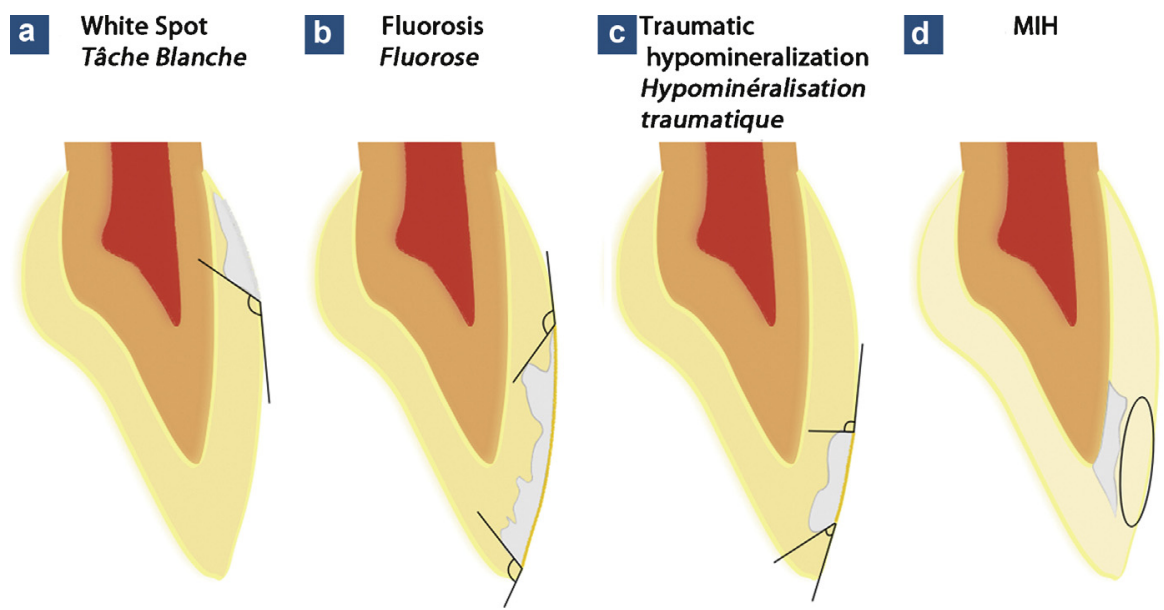

Fig. 19: Schematic representation of the topographical particularities of hypomineralization according to etiology: a: hypomineralization in white spots extends through the subsurface layer at an obtuse angle. The whole of the lesion is accessible to infiltration of resin during an "erosion-infiltration" procedure; b: hypomineralization in fluorosis is very similar to that of white spots in terms of topography and angulation. Involvement of the whole surface of the enamel is variable. "Erosion-infiltration" combined with in-office bleaching can represent an effective minimum level of treatment; $\mathbf{c}$ : hypomineralization in traumatic hypomineralization, although located in the subsurface layer, presents angular variations that are difficult to appreciate clinically. Resin infiltration during erosion-infiltration treatment is incomplete in acute angles (on the free margin side) leading to unsightly edge effects. In such situations, a degree of caution is required when envisaging treatment by "erosion-infiltration"; $d$ : the internal localization of hypomineralization in "mild" MIH is currently an obstacle to so-called "minimal" treatment. "Erosion-infiltration" is therefore not indicated.

Fig. 19 : Représentation schématique des particularités topographiques des hypominéralisations selon leur étiologie : a : l'hypominéralisation des white spots s'étend en subsurface selon une angulation obtus. L'intégralité de la lésion est accessible par la résine d'infiltration lors d'une procédure d'“ érosion-infiltration "; b : l'hypominéralisation d'une fluorose est très similaire à celles des white spots de par sa topographie et son angulation. Son étendue à toute la surface de l'émail est variable. L'“ érosion-infiltration » associée à un éclaircissement ambulatoire peut être une proposition thérapeutique a minima efficace ; c : l'hypominéralisation des hypominéralisations traumatiques, bien qu'étant de subsurface, présente des variations d'angulation qu'il est difficile d'appréhender cliniquement. L'infiltration résineuse lors d'un traitement par « érosioninfiltration » est incomplète au niveau des angulations aiguës (du côté du bord libre) conduisant à des « effets de bord » disgracieux. Dans ces situations, une certaine prudence est requise vis-àvis de leur traitement par « érosion-infiltration » ; $d$ : la localisation interne de l'hypominéralisation des « MIH légère » est actuellement un obstacle au traitement dit « a minima ». L'« érosioninfiltration » n'est donc pas indiquée.

MIH are not subject to mechanical degradation of the substrate, it seems reasonable to abstain from treatment.

\section{Conclusion}

Enamel hypomineralization, with varying degrees of severity, is the common feature of WS, fluorosis, traumatic hypomineralisation and MIH. The resulting reduction of the mineral phase compared to healthy enamel leads to intrinsic optical modifications causing white marks. However, in each attendant, les incisives porteuses d'une «MIH légère » n'étant pas sujet à des délabrements mécaniques de substrat, il est raisonnable de favoriser l'abstention.

\section{Conclusion}

L'hypominéralisation amélaire est le point commun, selon divers degrés d'atteinte, aux WS, aux fluoroses, aux hypominéralisations traumatiques et aux $\mathrm{MIH}$. La diminution de la phase minérale comparativement à l'émail sain qui en découle conduit à des modifications optiques intrinsèques 
pathological context this hypomineralization assumes different topographical forms (fig. 19), each requiring a specific therapeutic approach. Prior diagnosis of these forms is obviously an essential prerequisite to treatment. This leads to better understanding of the anatamopathology and shows that WS and fluorosis are broadly comparable, allowing treatment by erosion-infiltration to be indiscriminately applied. Traumatic hypomineralization is also a comparable situation, although variation of surface angles should encourage greater caution. Finally, it is only in the case of mild MIH, where hypomineralization is located internally, that abstention is recommended. A forthcoming article will present all possible treatments for these marks, along with a new modification to the erosion-infiltration protocol making it possible to treat hypomineralization resulting from MIH.

\section{Disclosure of interest}

The authors declare that they have no conflicts of interest concerning this article. responsables de taches blanches. Seulement, cette hypominéralisation acquiert selon chaque pathologie différentes formes topographiques (fig. 19) qui conduisent à devoir adapter spécifiquement leur approche thérapeutique. Leur diagnostic préalable devient évidemment un prérequis indispensable à leur prise en charge. Les connaissances anatomopathologies qui en découlent, informent que les WS et les fluoroses sont globalement comparables. C'est ce qui assure la possibilité d'appliquer indistinctement le protocole d'érosion-infiltration. Les hypominéralisations traumatiques peuvent également y être assimilées malgré la variabilité de son angulation de surface amenant à une plus grande prudence. Finalement, seule la localisation interne de l'hypominéralisation des $\mathrm{MIH}$ légères amène actuellement à une abstention. Dans un prochain article, nous présenterons tous les traitements possibles de ces taches, puis nous proposerons une modification originale du protocole de l'érosion-infiltration qui permettra de traiter les hypominéralisations liées aux MIH.

\section{Déclaration d'intérêts}

Les auteurs déclarent ne pas avoir de conflits d'intérêts en relation avec cet article.

\section{References/Références}

1. Gorelick L, Geiger AM, Gwinnett AJ. Incidence of white spot formation after bonding and banding. Am J Orthod 1982;81(2):93-8.

2. Richter AE, Arruda AO, Peters MC, Sohn W. Incidence of caries lesions among patients treated with comprehensive orthodontics. Am J Orthod Dentofacial Orthop 2011;139 (5):657-64.

3. Øgaard B. Prevalence of white spot lesions in 19-year-olds: a study on untreated and orthodontically treated persons 5 years after treatement. Am J Orthod Dentofacial Orthop 1989;96(5):423-7.

4. Ismail AI, Sohn W, Tellez M, et al. The international caries detection and assessment system (ICDAS): an integrated system for mesuring dental caries. Community Dent Oral Epidemiol 2007;35(3):170-8.

5. $\quad$ Selwitz RH, Ismail AI, Pitts NB. Dental caries. Lancet 2007;369:51-9.

6. Kielbassa AM, Müller J, Gernhardt CR. Closing the gap between oral hygiene and minimally invasive dentistry: a review on the resin infiltration technique of incipient (proximal) enamel lesions. Quintessence Int 2009;40:663-81.

7. Silverstone LM. Structure of carious enamel, including the early lesion. Oral Sci Rev 1973;3:100-60.

8. Kaqueler JC, Le May O. Lésions carieuses de l'émail. Anatomie pathologique buccodentaire. Éd. Masson, Paris p. 41-58 1998.

9. Pearce EIF, Nelson DGA. Microstructural features of carious human enamel imaged with back-scattered electrons. J Dent Res 1989;68(2):113-8.

10. Palamara J, Phakey PP, Rachinger WA, Orams HJ. Ultrastructure of the intact surface zone of white spot and brown spot carious lesions in human enamel. Oral Pathol 1986;15:28-35.

11. Wang LJ, Tang RK, Bonstein T, Orme CA, Bush PJ, Nancollas GH. A new model for nanoscale enamel dissolution. J Phys Chem 2005;109:999-1005. 
White defects on enamel: Diagnosis and anatomopathology: Two essential factors for proper treatment (part 1)

Taches blanches de l'émail : diagnostic et anatomopathologie : deux données indispensables pour bien les traiter (partie 1)

12. Atlan A, Denis M, Tirlet G, Attal JP. L'érosion-infiltration : un nouveau traitement des taches blanches de l'émail. Clinic 2012 (Hors série l'esthétique à la française):23-9 .

13. Sixou JL, Bailleul-forestier I. Recommandation sur la préscription des fluorures de la naissance à l'adolescence. J Odontol Stomatol Pediatr 2004;11(3):157-68.

14. Hescot P, Roland E. La santé dentaire en France en 1998. UFSBD, Paris p. 1261999.

15. Fortier JP, Demars-Fremault C. Abrégé de pédodontie. Masson édit, Paris 1987.

16. Fejerskov O, Larsen MJ, Richards A, Baelum V. Dental tissue effects of fluoride. Adv Dent Res 1994;8(1):15-31.

17. Yanagisawa T, Takuma S, Fejerskov O. Ultrastructure and composition of enamel in human dental fluorosis. Adv Dent Res 1989;3(2):203-10.

18. Wright JT, Chen SC, Hall KI, Yamauchi M, et al. Protein characterization of fluorosed human enamel. J Dent Res 1996;75(12):1936-41.

19. Riordan PJ. Perceptions of dental fluorosis. J Dent Res 1993;72:1268-74.

20. Marshman Z, Gibson B, Robinson PG. The impact of developmental defects of enamel on young people in the UK. Community Dent Oral Epidemiol 2009;37:45-57.

21. Tirlet G, Fron H, Attal JP. Infiltration, a new therapy for masking white spots on enamel: a case series with 19-month follow-up. Eur J Esthet Dent 2013.

22. Von Arx T. Developmental disturbances of permanent teeth following trauma to the primary dentition. Aust Dent J 1993;38(1):1-10.

23. De Amorim LFG, Estrela C, Da Costa LRRS. Effects of traumatic dental injuries to primary teeth on permanent teeth-a clinical follow-up study. Dent Traumatol 2011;27:117-21.

24. Thylstrup A, Andreasen JO. The influence of traumatic intrusion of primary teeth on their permanent successors in monkeys. A macroscopic, polarized ligiit and scanning electron microscopic study. J Oral Pathol 1977;6:296-306.

25. Andreasen JO, Sundström B, Ravn JJ. The effect of traumatic injuries to primary teeth on their permanent successors. I. A clinical and histologic study of 117 injured permanent teeth. Scand J Dent Res 1971;79:219-83.

26. Weerheijm KL, Duggal M, Mejàre I. Judgement criteria for Molar-IncisorHypomineralisation (MIH) in epidemiologic studies: a summary of the European meeting on MIH held in Athens, 2003. Eur Arch Paediatr Dent 2003;3:110-3.

27. Crombie FA, Manton DJ, Weerheijm KL, Kilpatrick NM. Molar-IncisorHypomineralisation: a survey of members of the Australian and New Zealand Society of Paediatric Dentistry. Aust Dent J 2008;53(2):160-6.

28. Rodd HD, Boissonade FM, Day PF. Pulpal status of hypomineralised permanent molars. Pediatr Dent 2007;29:514-20.

29. Chawla N, Messer LB, Silva M. Clinical studies on molar-incisor hypomineralisation. Part 2: Development of a Severity Index. Eur Arch Paediatr Dent 2008;9(4):191-9.

30. Lygidakis NA, Dimou G, Briseniou E. Molar-incisor hypomineralisation (MIH). Retrospective clinical study in Greek children. I. Prevalence and defect characteristics. Eur Arch Paediatr Dent 2008;9(4):200-6.

31. Farah R, Drummond B, Swain M, Williams S. Linking the clinical presentation of molarincisor hypomineralisation to its mineral density. Int J Paediatr Dent 2010;20:353-60.

32. Beentjes VEVM, Weerheijm JL, Groen HM. Factors involved in the aetiology of molarincisivor hypomineralisation (MIH). Eur J Paediatr Dent 2002;3(1):9-13.

33. Jälevik B, Norén JG. Enamel hypomineralisation of permanent first molars: a morphological study and survey of possible aetiological factors. Int J Paediatr Dent 2000;10(4):278-89.

34. Fearne J, Anderson P, Davis GR. 3D X-ray microscopic study of the extent of variations in enamel density in first permanent molars with idiopathic enamel hypomineralisation. $\mathrm{Br}$ Dent J 2004;196(10):634-8.

35. Xie ZH, Kilpatrick NM, Swain MV, Munroe PR, Hoffman M. Transmission electron microscope characterization of molar-incisor-hypomineralisation. J Mater Sci Mater Med 2008;19(10):3187-92. doi: 10.1007/s10856-008-3441-2 [Epub 2008 Apr 26].

36. Fagrell TG, Dietz W, Jälevik B, Norén JG. Chemical, mechanical and morphological properties of hypomineralised enamel of permanent first molars. Acta Odontol Scand 2010;68:215-22. 